\title{
Do Economic Conditions Still Cause Crime? Some Comforting Empirical Evidences from EU Panel*
}

\author{
Mindaugas Butkus ${ }^{1}$, Kristina Matuzevičiūtè $\dot{e}^{2}$ \\ Alma Mačiulytè-Šniukiené ${ }^{3}$
}

\begin{abstract}
Higher crime rates lead to the increasing fear and anxiety in society and disturb the social structure and harmony in the country. In the last decades, many scientists depict a decrease in economic factors, such as GDP per capita, unemployment rate, poverty, etc. as the primary drivers of crime both in developed and in developing countries. Even during the periods of economic crises, crime rates in the European Union (EU) continued to either decline or remain the same, thus bringing into question the impact of economic factors on crime rates in the $E U$. The paper examines the impact of changing economic conditions on crime rates in EU countries, employing nowadays vastly used methods in economics to address endogeneity. The aim of the paper is to empirically estimate the relationship between crime rates and economic factors, using previously developed methods. After a series of robustness checks, estimations did not provide evidence of a significant relationship between economic conditions and crime rates over the last decade in EU countries, except for homicides in some model specifications.
\end{abstract}

Key words: crime rates, crime prevention, economic conditions, panel data, GMM estimator

JEL classification: $K 14, K 42, E 32$

* Received: 16-10-2018; accepted: 02-12-2019

1 Associate professor, Department of Economic Engineering, Vilnius Gediminas Technical University, Sauletekio av. 11, LT-10223 Vilnius, Lithuania. Scientific affiliation: quantitative methods in economics, econometrics. Phone: +370671 02658.E-mail: mindaugas.butkus@ vgtu.lt.

2 Associate professor, Department of Economic Engineering, Vilnius Gediminas Technical University, Sauletekio av. 11, LT-10223 Vilnius, Lithuania. Scientific affiliation: national and regional development, international labour migration. Phone: +370614 33446. E-mail: kristina.matuzeviciute-balciuniene@vgtu.lt.

${ }^{3}$ Associate professor, Department of Business Technologies, Vilnius Gediminas Technical University, Sauletekio av. 11, LT-10223 Vilnius, Lithuania. Scientific affiliation: regional development, competitiveness. Phone: +370 652 71009. E-mail: alma.maciulyte-sniukiene@ vgtu.lt (corresponding author). 


\section{Introduction}

During the last decades, the common concept that irregularities in the business cycle are related to changes in different crime rates has been the subject of debate for states, international organizations, scientists, and societies. Studies link the decreasing economic development to lower social trust, impaired mental and physical health, excessive consumption, drug addiction, obesity, and failing education systems. Moreover, the decreasing or negative economic growth and rapidly increasing unemployment have a negative impact on a large number of individuals and sudden reductions in income (Saridakis and Spengler 2012; DixCarneiro et al., 2016; De Blasio et al., 2016; Hargaden, 2016; Hazra and Cui, 2018). All that, in turn, causes an increase in the proportion of the population with a higher motivation to commit crimes solving their immediate problems. Nonetheless, scientists have noted that other non-economic factors, such as demographic composition (Greenberg, 2014; Engelen et al., 2016, Brosnan, 2018), socioeconomic status and gender (Wrigley-Asante, 2016), have an increasingly higher impact on the dynamics of crime rates than economic factors in developed countries over the past decade.

Economically developed nations, such as the European Union (EU) countries, the United States of America (USA), Canada, etc., despite their difference in domestic or foreign policies, all share one similar trait - these states are economically sound. Therefore, more economically developed countries can focus their national resources to improve such sectors as education, national healthcare, to develop new technologies, etc., to increase the quality of life for their citizens. Therefore, ever-changing economic situation, aftermaths of global economic crises, or consequences of inadequate fiscal or monetary policy, changes in production cost that shift business throughout different regions, etc. might not so greatly affect standards of living and crime rates in developed countries anymore. Therefore, using the EU panel, we aim to challenge the orthodox view that the decreasing economic development along with its consequences has become the main cause of the increasing criminal activity. Therefore, we hypothesize that the relationship between economic conditions and crime rates is weak.

The rest of the paper is organized according to the research objectives: in Section 2 , we present a literature review on the relationship between economic conditions and crime rates. In Section 3, we describe variables, data and ground specification of the model that would allow to empirically test our hypothesis. In Section 4, we present estimation results and robustness checks, generated using EViews 10 software, and summarise research findings. In Section 5, we provide general results and comparisons with the previous studies, discussion, and scientific contribution. The last section concludes the paper. 


\section{Literature review}

Crime and the factors affecting crime rates in different countries have been a long-standing research interest of both sociologists and economists, but according to Engelen et al. (2016), there exists no panacea definition of crime, or an economic or sociological theory explaining the conditions affecting certain shifts in crime rates. Traditionally, sociologists aim to explain the shifts in crime rates through the exploration of the influence of social structure and institutions on crime rates, thereby connecting the increase or decrease in crime rates to social disorganization, i.e. focusing on an individual's motivation for engaging in criminal activities. However, the sociological approach to analysed changes in crime rates focuses more on individual-level data rather than taking into account the macroeconomic level. The economic approach to the increasing and/or decreasing crime rates, on the other hand, focuses on the macroeconomic factors, such as gross domestic product (GDP), unemployment, poverty, amount of law enforcement, etc., thereby, focusing on the factors affecting a larger part of the population.

The concept of crime is widely understood as an activity, which is against the law and, therefore, is punishable upon conviction. The link between the increase and decrease in regard to criminal activities and an opposite shift in economic factors has been the interest of economic research since the emergence of the works by the economist Becker in the 1960s. However, while the literature related to crime and economic factors is vast, no single widely accepted definition or model to analyse factors affecting crime rates exists. Most of the empirical studies focus on the situation in the USA, but there is a lack of studies in EU countries.

From a theoretical perspective, factors or conditions affecting crime rates can be analysed in three aspects: offender motivations, economic outcomes, and economic process. However, both the first and the second aspects focus on the analysis of factors influencing crime rates either on the motivation for economic gain or the economic return provided by legal acts to offenders. Therefore, to analyse the impact of economic factors on crime rates in the EU countries, the third economic tradition is utilized, which states, that the processes responsible for the shifts in crime rates are the same that guide the consumer behaviour in the marketplace. Therefore, the actions of people are understood as rational, seeking to maximize their self-interests. People weigh the cost-benefit of criminal activities and decide to opt for criminal activity or not, e.g. legal parking versus parking illegally in a spot of convenience. Therefore, a high cost of apprehension for a criminal outweighs the benefits that can be received from committing a crime. The economists also note that the impact of positive and/or negative habits, such as alcoholism, drug use, etc. can have a positive impact on the crime rates. Table 1 shows the determinants of crime in the literature. 
Mindaugas Butkus et al. • Do Economic Conditions Still Cause Crime?...

\begin{tabular}{|c|c|c|c|c|c|c|c|c|c|c|c|c|}
\hline 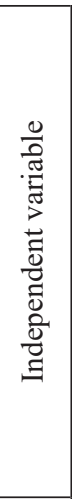 & 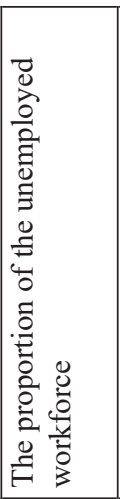 & 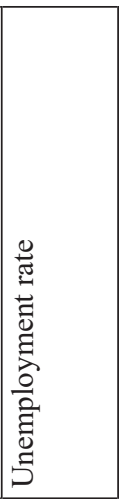 & 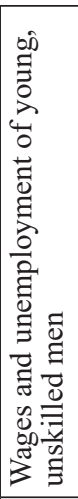 & 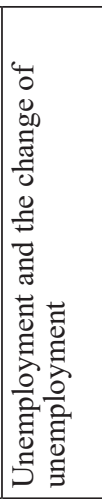 & 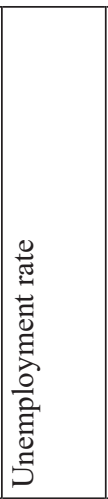 & 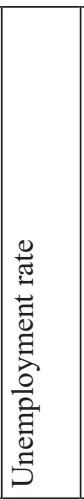 & 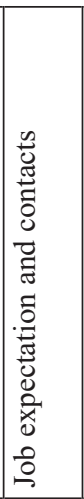 & 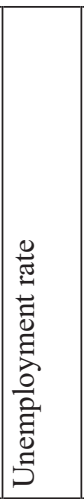 & 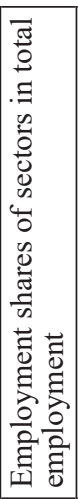 & 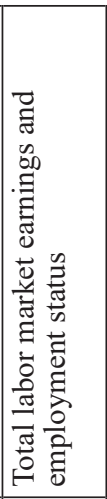 & 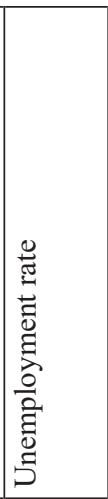 & $\begin{array}{l}0 \\
0 \\
0 \\
0 \\
3 \\
0 \\
0 \\
0 \\
0 \\
0 \\
0 \\
0 \\
0 \\
1 \\
0 \\
0 \\
0 \\
0 \\
0\end{array}$ \\
\hline 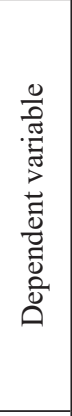 & 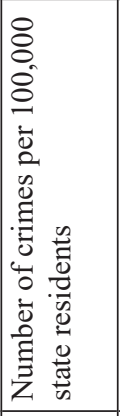 & 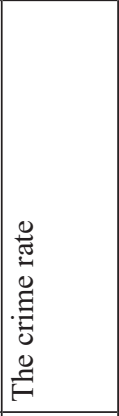 & 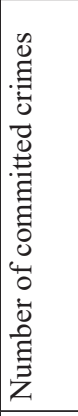 & 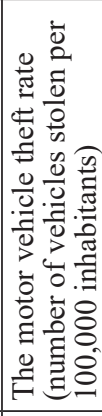 & 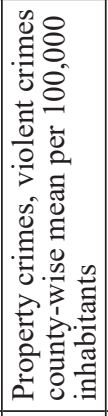 & 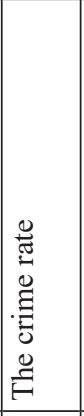 & 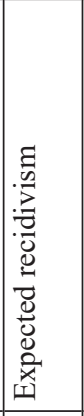 & 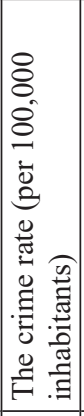 & 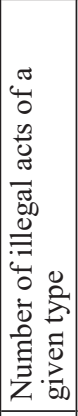 & 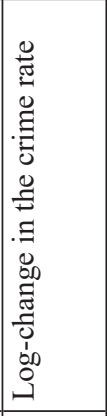 & 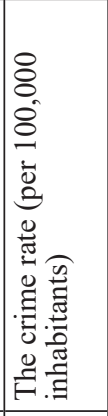 & 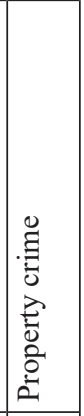 \\
\hline 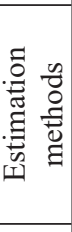 & 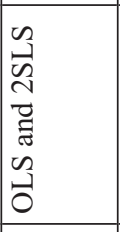 & 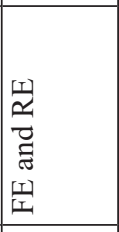 & $\begin{array}{l}n \\
1 \\
\tilde{N} \\
N \\
0 \\
0 \\
0 \\
n \\
0 \\
0\end{array}$ & 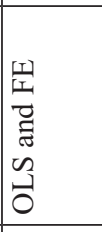 & 臭 & 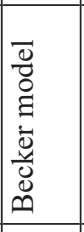 & 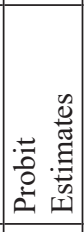 & $\sum_{\circlearrowright}$ & 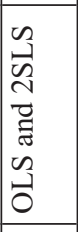 & 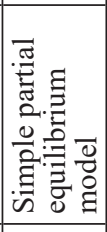 & 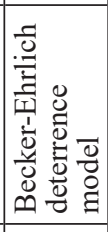 & 띤 \\
\hline $\begin{array}{l}\overrightarrow{\tilde{\Xi}} \\
\text { : } \\
\text { : }\end{array}$ & + & + & + & - & + & + & + & + & ' & 1 & + & 1 \\
\hline 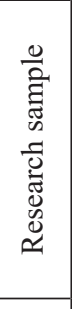 & 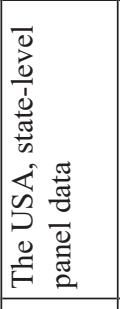 & 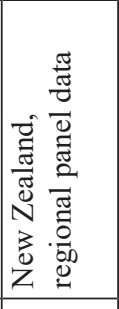 & 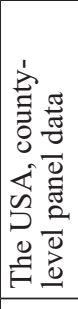 & 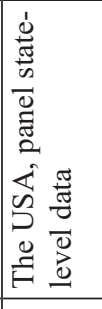 & 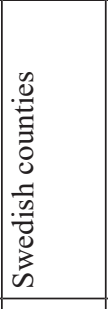 & 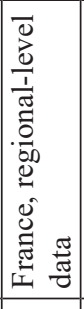 & 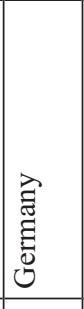 & 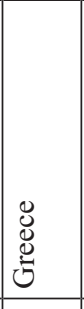 & 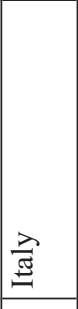 & 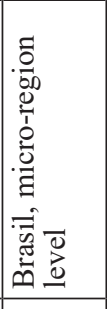 & 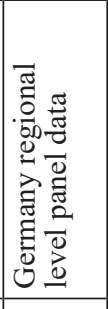 & 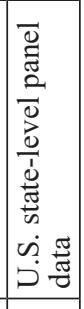 \\
\hline 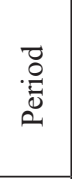 & $\frac{\hat{a}}{\frac{1}{a}}$ & 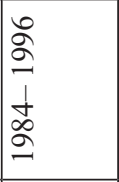 & $\begin{array}{l}\hat{a} \\
\frac{a}{1} \\
\frac{1}{2} \\
\frac{2}{2}\end{array}$ & ¿্ণ & $\begin{array}{l}2 \\
2 \\
1 \\
\infty \\
\infty \\
2\end{array}$ & $\begin{array}{l}8 \\
8 \\
0 \\
1 \\
1 \\
2 \\
2 \\
2\end{array}$ & $\begin{array}{l}0 \\
0 \\
0 \\
\text { N } \\
1 \\
\text { ôे } \\
0 \\
\text { ì }\end{array}$ & $\begin{array}{l}\infty \\
2 \\
\frac{1}{1} \\
2 \\
2\end{array}$ & $\begin{array}{l}0 \\
0 \\
0 \\
i \\
1 \\
1 \\
0 \\
0 \\
i\end{array}$ & \begin{tabular}{l}
0 \\
\hdashline \\
$\stackrel{1}{1}$ \\
1 \\
$\infty$ \\
2 \\
2
\end{tabular} & $\begin{array}{l}2 \\
1 \\
\vdots \\
\vdots \\
2\end{array}$ & 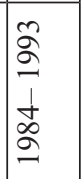 \\
\hline 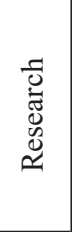 & 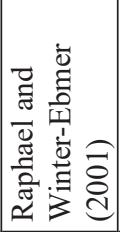 & 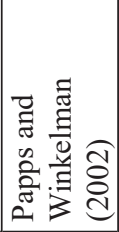 & 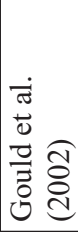 & 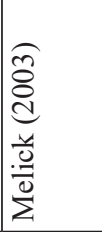 & 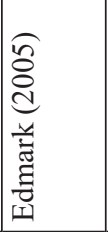 & 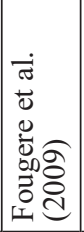 & 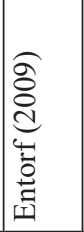 & 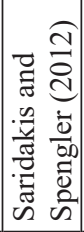 & 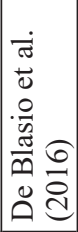 & 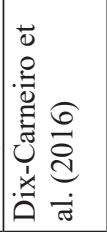 & 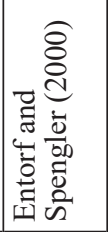 & 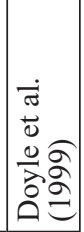 \\
\hline
\end{tabular}




\begin{tabular}{|c|c|c|c|c|c|c|c|}
\hline 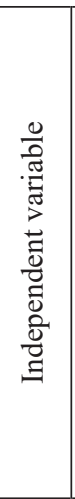 & 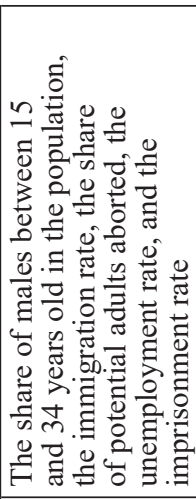 & 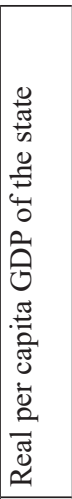 & 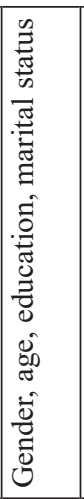 & 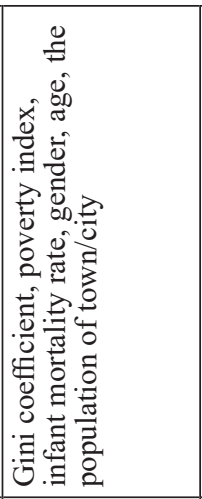 & 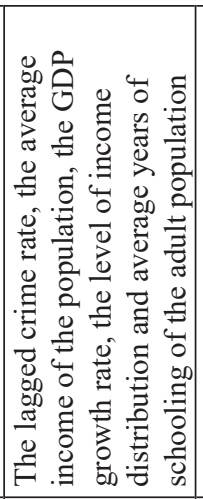 & 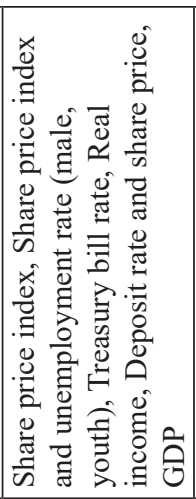 & 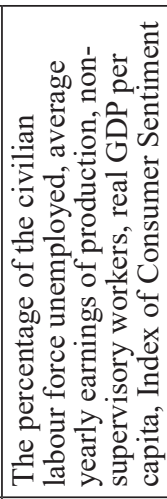 \\
\hline 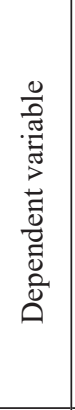 & 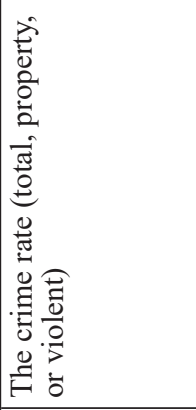 & 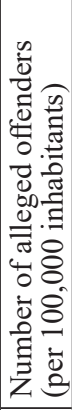 & 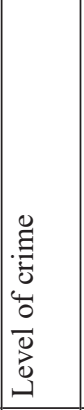 & 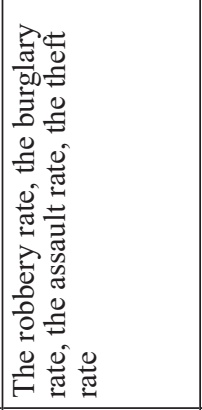 & 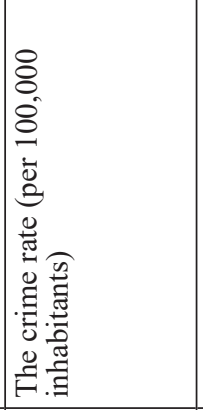 & 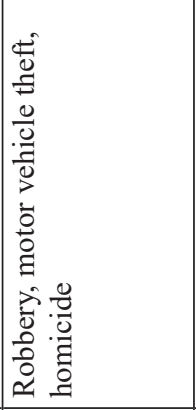 & 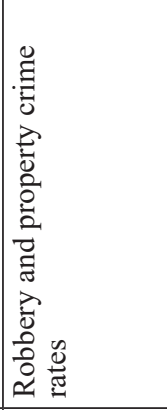 \\
\hline 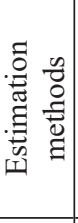 & 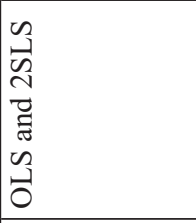 & 壵 & 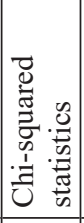 & 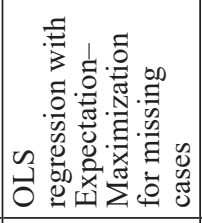 & $\sum_{j}$ & 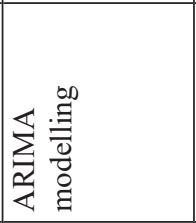 & 告 \\
\hline $\begin{array}{l}\text { 芯 } \\
\text { : } \\
\text { 品 }\end{array}$ & - & ' & + & - & + & - & ' \\
\hline 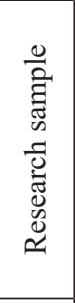 & 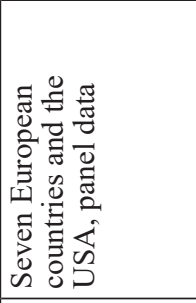 & 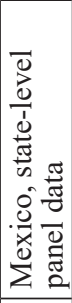 & 尝 & 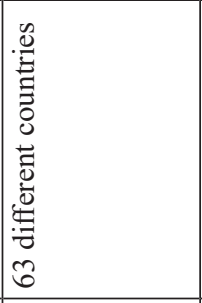 & 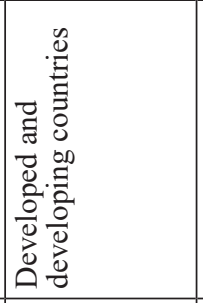 & 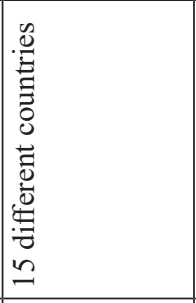 & 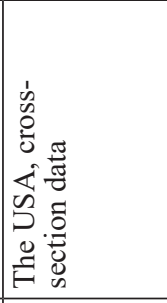 \\
\hline $\begin{array}{l}\overrightarrow{0} \\
\stackrel{0}{0} \\
2\end{array}$ & $\begin{array}{l}\infty \\
0 \\
0 \\
i \\
1 \\
0 \\
0 \\
2 \\
=\end{array}$ & 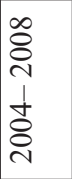 & 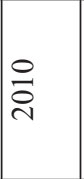 & $\begin{array}{l}8 \\
8 \\
0 \\
1 \\
1 \\
2 \\
2\end{array}$ & 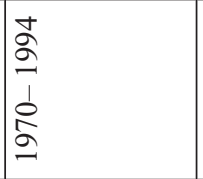 & $\begin{array}{l}8 \\
8 \\
i \\
1 \\
\frac{1}{2} \\
2\end{array}$ & 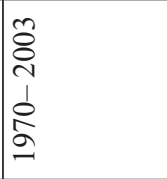 \\
\hline 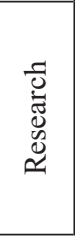 & 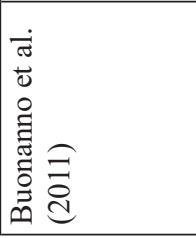 & 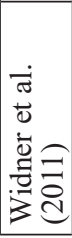 & 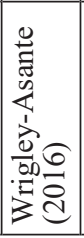 & 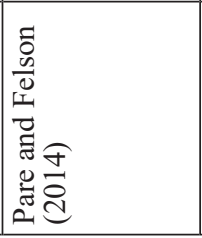 & 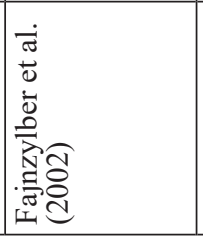 & 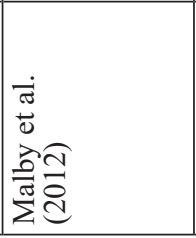 & 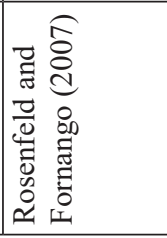 \\
\hline
\end{tabular}


There have been many efforts to conduct research on the relationship between different economic factors and crime rates, but the results are unclear and most of the studies are focused on the United States. A few studies carried out in Europe analyse the data on crime and economic factors only in one country and there is no research analysing this relationship in the EU country panel. The general consensus regarding the relationship between unemployment and crime rates that was empirically grounded by Raphael and Winter-Ebmer (2001) in the USA is that the negative changes in the labour market (i.e. an increasing unemployment rate) lead to an increase in crime rates, while positive changes in the labour market and economy lead to a decrease in crime rates. This was later confirmed by other researchers (Papps and Winkelman, 2002; Gould et al., 2002; Melick, 2003; Edmark, 2005; De Blasio et al., 2016; Dix-Carneiro et al., 2016), using OLS, FE and RE estimators which enabled to control time and area fixed effects and areaspecific time trends. Over the last ten years, many researchers have used these models and they have consistently concluded the relationship between labour market conditions and crime rates. Fougere et al. (2009) examined the influence of youth unemployment on the property and on violent crimes in France, using the Becker-type model. Saridakis and Spengler (2012), using the Generalized Method of Moments (GMM) estimator to deal with the endogenous variables, estimated the relationship between crime, deterrence, and unemployment in Greece. Entorf (2009), using the probit estimates, provided the microeconometric evidence on the relationship between the anticipated labour market opportunities and the perceived probability of future recidivism. Doyle et al. (1999) used fixed effects to control unobserved heterogeneity across states and measured labour market opportunities. The other group of researchers (Entorf and Spengler, 2000; Buonanno et al., 2011; Widner et al., 2011; Greenberg, 2014; Engelen et al., 2016; Wrigley-Asante, 2016) emphasized the impact of demographic and socioeconomic conditions.

The unemployment rate is one of the most analysed economic factors in the research, as it is presumed to give the most accurate and definitive representation of the health of a country's economy and labour market. As Mustard (2010) explains, there is a gap between theory and empirical research in terms of data and econometric techniques, identifying the relationship between unemployment and crime rates. The lack of an unambiguous conclusion on the relationship between crime and economic conditions is caused by a country's specific culture and diversity associated with how to define and classify crime, as well as to how society reacts to the crime problem (Rose, 2006). Attempts to clarify the relationship between crime and economic conditions have remained the main issues in crime research that influence the relevance of this research creating scientifically based assumptions for crime preventing policies. 


\section{Methodology}

This section provides the motivation and descriptive statistics on alternative variables used to proxy the economic conditions and controls that might affect crime, the specification of the model used to empirically test hypothesis, and the justification of the general estimation method.

Based on the previous research conducted by scientists, the economic factors, such as GDP per capita, unemployment, etc. can have a relationship with the dynamics of the crime rates. For the analysis of the effect of economic conditions on crime rates, we used the data provided by Eurostat. Based on the research conducted by Raphael and Winter-Ebmer (2001), Cook and Zarkin (1985), Gould et al. (2002), the crimes are categorized into four categories, thus we use four dependent variables of crime: i) Violent crime (composed out of robbery, rape, and sexual assault); ii) Homicides (intentional); iii) Property crime (composed out of burglary, theft, and theft of a motorized land vehicle); iv) Unlawful acts involving controlled drugs or precursors. The division of crime into four categories is based on the findings that different crime rates are differently affected by certain macroeconomic factors, and analysing the effects of macroeconomic factors on the total crime rate in the EU panel, which are declining, do not shed all light on the relationships. The data on crime, obtained from Eurostat, is for all current EU countries, except the UK $(\mathrm{N}=27)$ over the period 2008-2016 ( $\mathrm{T}=9)$.

Based on the studies conducted by the above-mentioned scientists, two main economic factors indicating the strength of the economy and labour market are (i) real GDP per capita and (ii) unemployment rate. Real GDP per capita provided by Eurostat is used to proxy a person's average wage/income. It is expected that the increase in GDP per capita should lead to a decrease in crime and vis-à-vis. We expect to see a positive relationship between unemployment and crime rates. Additionally, several control variables are included to either minimize and/or rule out the possibility that social factors are confounding the relationship between economic factors and the crime rate in the estimations. The control variables are based on those which were included by Cook and Zarkin (1985) while examining how economic conditions affect crime rates. Therefore, control variables are (i) education spending; (ii) police, courts and prison spending, and (iii) population.

The above-mentioned control variables control the possibility that crime rates are influenced primarily by the quantity of police force, long-term economic investment of the state in the further economic potential of its people. The research in the dynamics of crime rates both by Levitt (1996) and Ehrlich (1996) has provided conclusive results that the increased state spending regarding police and/or education spending may result in the decline of the crime rate. Table 2 summarises all variables used in the analysis and presents the descriptive statistics as well. 
Table 2: Definitions and descriptive statistics of variables

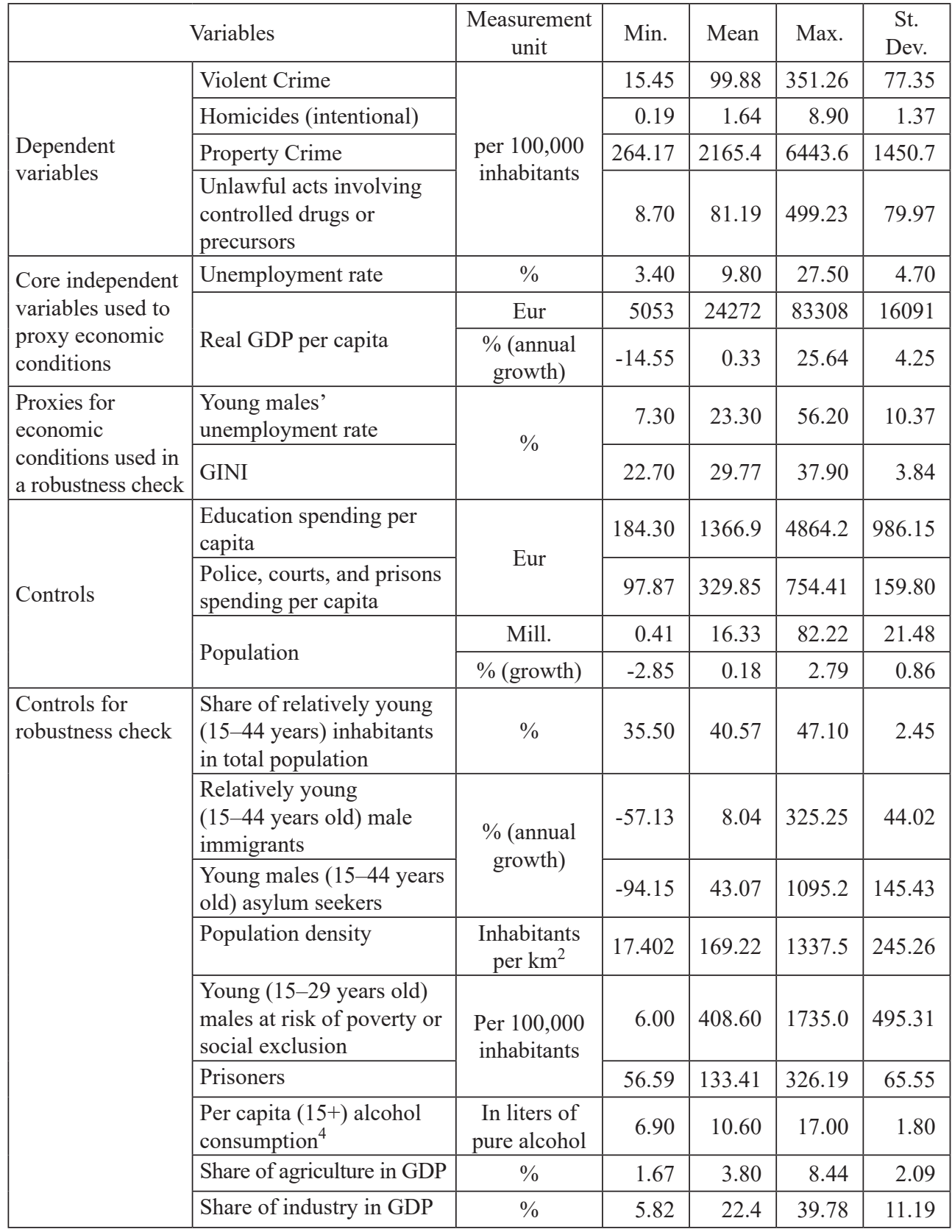

Source: Authors' calculations

$\overline{4}$ The only one variable collected from World Health Organization database, the rest of the data is provided by Eurostat. 
Since the panel data contain two complementary dimensions of cross-section and time, this data typically provides more information and variability, an increased degree of freedom, and a decreased degree in potential collinearity problems among the variables compared to one-dimensional data. Thus, the panel data provide more effective estimates. Our proposed dynamic panel data model (in unobserved effects form) takes the following general form:

$$
\text { crime }_{i, t}=\alpha+\delta \text { crime }_{i, t-1}+\beta_{I} g d p_{i, t}+\beta_{2} \text { unem }_{i, t}+c_{1} e d u c_{i, t}+c_{2} \text { pol }_{i, t}+c_{3} \text { pop }_{i, t}+\mu_{i}+\eta_{t}+\varepsilon_{i, t}
$$

where $i=1, \ldots, \mathrm{N}$ for each country in the panel and $t=1, \ldots, \mathrm{T}$ refers to the time period. The given variables are in a form of the natural logarithm. Variable crime represents four alternative variables pertaining to crime, $g d p$ - real gross domestic product per capita that is used to proxy wages, unem - unemployment rate, educ - expenditures on education, $\mathrm{pol}$ - expenditures on police, courts and prisons, and pop - population in the country. $\mu$ represents the unobserved country fixed-effects; $\eta$ represents the time-specific effects. The parameters $\beta_{1}, \beta_{2}$ and $c_{1}, \ldots, c_{5}$ represent the long-run elasticity estimates of crime rates with respect to the corresponding factor. $\varepsilon$ is the classical error term which is assumed to be independent and identically distributed.

The classical estimation methods like OLS, the fixed or random effects for the panel regression models do not seriously address an endogeneity problem in the dynamic framework. Moreover, it is very likely, that incentives to increase spending on police forces are growing with higher crime rates. A similar theoretical background for reverse causality could be also applied to the remaining right-hand side variables of Eq. (1). This would lead to the biased effects of factors on crime rates. There has been an extensive search for variables not subject to reverse causality for using them as instruments, but these variables (e.g. origins of a country's legal systems or human rights, etc.) have the drawback - they do not change over time, and because of that, we cannot use them with OLS or the fixed effects that take transformations to omit the time-constant effects. For this reason, following Arellano and Bover (1995), we can solve the endogeneity problem by employing the GMM estimator. Using the advantage of the panel type of data, the GMM estimator is grounded on the first-order differenced regressors to control unobserved effects. Taking into account time-specific effects, we obtain:

$$
\text { crime }_{i, t}-\text { crime }_{i, t-1}=\delta\left(\text { crime }_{i, t-1}-\text { crime }_{i, t-2}\right)+\beta\left(X_{i, t}-X_{i, t-1}\right)+\left(\varepsilon_{i, t}-\varepsilon_{i, t-1}\right)
$$

where $X$ is the set of all independent variables. The estimation of Eq. (2) requires an instrumental variable procedure to correct the endogeneity of the columns of $X$. This procedure is also necessary to correct the correlation between the error term and the lagged difference of the outcome variable. As it is difficult to find the instruments, particularly strictly exogenous, we are able to construct the internal 
predetermined instruments, using the lagged values of the independent variable. If we assume that $\mathrm{E}\left[\varepsilon_{i, t} \mid X_{i, s}\right]=0$ for all $t>s$ (but not otherwise), the second- and higherorder lags of the right-hand side variables can be used as the instruments in the estimation of Eq. (2). This condition is likely to hold and the second- and highorder lags of the endogenous variables are probably the valid instruments if the error is serially uncorrelated.

A simple GMM approach with the internal predetermined instruments, used to compute the difference estimator, has some drawbacks. Firstly, the first-differencing removes the long-run cross-country information presented in the levels of the variables. Secondly, if the independent variables are constant or subject to slow change over time, their lagged levels will be a poor instrument of their differences. Under additional assumption that $\mathrm{E}\left[\mu_{i} \mid X_{i, t}\right]=\mathrm{E}\left[\mu_{i} \mid X_{i, s}\right]$ and $\mathrm{E}\left[\mu_{i} \mid c_{i, t}\right]=\mathrm{E}\left[\mu_{i} \mid c_{i, s}\right]$ for all $t$ and $s$ it is possible to overcome these problems by constructing an alternative system-GMM estimator, using as suitably lagged differences of the dependent and independent variables as the instruments. If the error is serially uncorrelated, oncelagged differences of independent variables are valid instruments. According to Arellano and Bover (1995) and Blundell and Bond (1998), combining the level and first-difference equations, it is possible to construct a system-GMM estimator that overcomes drawbacks inherent to the difference estimator. Soto (2009), as well as Hayakawa (2007), analysed the properties of various GMM and other estimators, applying Monte Carlo simulations. They found that the system-GMM estimator is less biased than the first differencing or the level estimators.

To examine the overall validity of the system-GMM estimator, following Arellano and Bond (1991) and Blundell and Bond (1998), two tests are to be carried out: (1) the Sargan test which tests the null hypothesis that the instruments are valid; and (2) the $\operatorname{AR}(2)$ test which tests null hypothesis that there is no second-order serial correlation. The system-GMM estimation results are valid only after passing the two tests mentioned above.

\section{Empirical data and results}

This section presents the estimates of our initial specification, using the main estimation strategy as well as the robustness check that covers the alternative estimation strategies, an alternative set of control variables, the alternative proxies for economic conditions, and the alternative specifications to consider the possible effect of economic shock of 2008, the relationship with a time lag, and impact heterogeneity.

As explained above, the system-GMM was used to estimate Eq. (1). The estimates presented in Table 3 show that the relationship between the current crime rate and the one-year lagged crime rate is statistically significant and positive (except for intentional homicides). 
Table 3: General estimates using system-GMM

\begin{tabular}{|c|c|c|c|c|}
\hline Regressors & Violent Crime & $\begin{array}{l}\text { Homicides } \\
\text { (intentional) }\end{array}$ & $\begin{array}{l}\text { Property } \\
\text { Crime }\end{array}$ & $\begin{array}{c}\text { Unlawful acts } \\
\text { involving } \\
\text { controlled drugs or } \\
\text { precursors }\end{array}$ \\
\hline $\mathrm{Y}(-1)$ & $\begin{array}{r}0.7732 * * * \\
(5.0725)\end{array}$ & $\begin{array}{r}0.1409 \\
(0.6725)\end{array}$ & $\begin{array}{r}0.8184 * * * \\
(3.7343)\end{array}$ & $\begin{array}{r}0.6814 * * * \\
(4.3256)\end{array}$ \\
\hline Constant & $\begin{array}{r}-1.3665 \\
(-1.1966)\end{array}$ & $\begin{array}{r}3.6835 \\
(1.3309)\end{array}$ & $\begin{array}{r}0.4947 \\
(0.4887) \\
\end{array}$ & $\begin{array}{r}1.6574 \\
(0.9344) \\
\end{array}$ \\
\hline Unemployment rate & $\begin{array}{l}0.0757) \\
(1.4136\end{array}$ & $\begin{array}{l}0.2798^{*} \\
(1.9306)\end{array}$ & $\begin{array}{r}-0.0541 \\
(-0.6700)\end{array}$ & $\begin{array}{r}0.0445 \\
(0.4265)\end{array}$ \\
\hline Real GDP per capita & $\begin{array}{r}0.1066 \\
(0.3197)\end{array}$ & $\begin{array}{r}-0.4544 \\
(-0.8529)\end{array}$ & $\begin{array}{r}0.0909 \\
(0.6534)\end{array}$ & $\begin{array}{r}-0.2595 \\
(-0.6269)\end{array}$ \\
\hline $\begin{array}{l}\text { Per capita government expenditures on } \\
\text { education }\end{array}$ & $\begin{array}{l}0.04464 \\
(0.1717)\end{array}$ & $\begin{aligned} 0.7101 \\
(1.3668)\end{aligned}$ & $\begin{array}{r}0.0482 \\
(0.1973)\end{array}$ & $\begin{array}{r}0.2895 \\
(0.8340)\end{array}$ \\
\hline $\begin{array}{l}\text { Per capita government expenditures on } \\
\text { police, courts and prisons }\end{array}$ & $\begin{array}{r}0.0971 \\
(0.4324)\end{array}$ & $\begin{array}{r}-0.7215 \\
(-1.2493)\end{array}$ & $\begin{array}{r}-0.0407 \\
(-0.2362)\end{array}$ & $\begin{array}{r}0.1008 \\
(0.3527)\end{array}$ \\
\hline Population & $\begin{array}{r}0.0215 \\
(0.6748)\end{array}$ & $\begin{array}{r}-0.0208 \\
(-0.4286)\end{array}$ & $\begin{array}{r}-0.0007 \\
(-0.0221)\end{array}$ & $\begin{array}{r}-0.0311 \\
(-0.4910)\end{array}$ \\
\hline $\mathrm{N}$ & 214 & 214 & 214 & 214 \\
\hline Number of countries & 27 & 27 & 27 & 27 \\
\hline $\mathrm{AR}(2)$ test & $\begin{array}{r}1.2439 \\
{[0.2135]}\end{array}$ & $\begin{array}{r}-0.47 \\
{[0.6338]}\end{array}$ & $\begin{array}{r}1.0499 \\
{[0.2938]}\end{array}$ & $\begin{array}{r}0.4106 \\
{[0.6814]}\end{array}$ \\
\hline Sargan test & $\begin{array}{r}17.3103 \\
{[0.8994]}\end{array}$ & $\begin{array}{r}18.0314 \\
{[0.8746]}\end{array}$ & $\begin{array}{r}19.6196 \\
{[0.8092]}\end{array}$ & $\begin{array}{r}13.5952 \\
{[0.9780]}\end{array}$ \\
\hline
\end{tabular}

Note: All variables are logged. All estimations are 2-steps ${ }^{5}$ system-GMM, including equations in levels and all of them include time dummies. The statistics given in the parentheses under the coefficients of explanatory variables are z-values using robust (Windmeijer-corrected) standard errors ${ }^{6}$. The statistics in the brackets of the AR(2)/Sagan test are p-values.

$*, * *, * * *$ indicate statistically significant at the $10 \%, 5 \%$, and $1 \%$ levels, respectively.

Source: Authors' calculations

All estimates show no evidence of a statistically significant relationship between variables that proxy economic conditions and crime rates (except for some minor positive correlation between the unemployment rate and intentional homicides). The same non-significant relationship is observed between crime rates and control variables. These findings are at some point unexpected but not impossible (Rosenfeld and Fornango, 2007; Malby et al., 2012). Having in mind that estimates may, to some extent, depend on variables used to proxy economic or other conditions or on estimation strategy, we performed an extensive robustness check

5 Once the 1-step estimator is computed, the sample covariance matrix of the estimated residuals is used to obtain 2-step estimates, which are not only consistent but also asymptotically efficient.

6 To take into account the concern of Blundell and Bond (1998) about the downward-biased tendency of standard errors estimated by the system-GMM approach for small samples, we used finite-sample corrections suggested by Windmeijer (2005) to the asymptotic covariance matrix of the parameters, which are nowadays almost universally used. 
to ensure that the general estimates are free of estimation strategy as well as of proxies in use, or of model specification. The general estimates were obtained using the system-GMM estimation strategy. Tables 4 and 5 provide the estimates of the same Eq. (1) using alternative methods that are also widely applied in the panel data context.

Table 4: Results of robustness to estimation method (1)

\begin{tabular}{|c|c|c|c|c|c|c|c|c|}
\hline \multirow{2}{*}{ Regressors } & \multicolumn{4}{|c|}{ Violent Crime } & \multicolumn{4}{|c|}{ Homicides (intentional) } \\
\hline & $\mathrm{OLS}^{(1)}$ & $\mathrm{FE}^{(2)}$ & $\mathrm{RE}^{(3)}$ & G2SLS $^{(4)}$ & OLS & FE & $\mathrm{RE}$ & G2SLS \\
\hline Constant & $\begin{array}{r}0.0854 \\
(1.6095)\end{array}$ & $\begin{array}{l}-43.77 * * \\
(-2.5358)\end{array}$ & $\begin{array}{r}-2.6850 \\
(-1.2969)\end{array}$ & $\begin{array}{l}-35.3725 \\
(-0.1878)\end{array}$ & $\begin{array}{r}-0.0503 \\
(-1.0473)\end{array}$ & $\begin{array}{r}-1.8739 \\
(-0.0819)\end{array}$ & $\begin{array}{r}6.126 * * * \\
(3.4467)\end{array}$ & $\begin{array}{l}-37.1872 \\
(-0.3928)\end{array}$ \\
\hline $\begin{array}{l}\text { Unemployment } \\
\text { rate }\end{array}$ & $\begin{array}{r}-0.1423 \\
(-1.1484)\end{array}$ & $\begin{array}{r}-0.0141 \\
(-0.1253)\end{array}$ & $\begin{array}{r}0.1667 * * \\
(2.3970)\end{array}$ & $\begin{array}{r}3.3245 \\
(0.2121)\end{array}$ & $\begin{array}{r}0.0875 \\
(0.4452) \\
\end{array}$ & $\begin{array}{r}0.0157 \\
(0.1137) \\
\end{array}$ & $\begin{array}{r}-0.0078 \\
(-0.0933)\end{array}$ & $\begin{array}{r}2.5404 \\
(0.3248)\end{array}$ \\
\hline $\begin{array}{l}\text { Real GDP per } \\
\text { capita }\end{array}$ & $\begin{array}{r}-0.0624 \\
(-0.1258)\end{array}$ & $\begin{array}{r}-0.1520 \\
(-0.2511)\end{array}$ & $\begin{array}{r}-0.1004 \\
(-0.4169)\end{array}$ & $\begin{array}{r}3.2780 \\
(0.2077)\end{array}$ & $\begin{array}{r}0.5663 \\
(0.5864)\end{array}$ & $\begin{array}{r}-0.0333 \\
(-0.0901)\end{array}$ & $\begin{array}{l}-0.4771 * \\
(-1.7266)\end{array}$ & $\begin{array}{r}3.2276 \\
(0.4065)\end{array}$ \\
\hline $\begin{array}{l}\text { Per capita } \\
\text { government } \\
\text { expenditures on } \\
\text { education }\end{array}$ & $\begin{array}{r}0.0138 \\
(0.0722)\end{array}$ & $\begin{array}{r}-0.1558 \\
(-0.5183)\end{array}$ & $\begin{array}{r}0.3768^{*} \\
(1.7445)\end{array}$ & & $\begin{array}{r}-0.1296 \\
(-0.5031)\end{array}$ & $\begin{array}{r}-0.0214 \\
(-0.0867)\end{array}$ & $\begin{array}{r}0.2690 \\
(1.0513)\end{array}$ & \\
\hline $\begin{array}{l}\text { Per capita } \\
\text { government } \\
\text { expenditures on } \\
\text { police, courts, } \\
\text { and prisons } \\
\end{array}$ & $\begin{array}{r}-0.0059 \\
(-0.0499)\end{array}$ & $\begin{array}{r}0.4970 \\
(1.5623)\end{array}$ & $\begin{array}{r}0.4074 * * \\
(2.0962)\end{array}$ & & $\begin{array}{r}-0.0048 \\
(-0.0215)\end{array}$ & $\begin{array}{r}-0.0121 \\
(-0.0550)\end{array}$ & $\begin{array}{r}-0.2384 \\
(-1.0231)\end{array}$ & \\
\hline Population & $\begin{array}{r}3.7230 \\
(4.1796)\end{array}$ & $\begin{array}{r}3.038 * * * \\
(2.9661)\end{array}$ & $\begin{array}{r}0.1782 * * \\
(2.1907)\end{array}$ & & $\begin{array}{r}1.7472 \\
(1.3829)\end{array}$ & $\begin{array}{r}0.1785 \\
(0.1213) \\
\end{array}$ & $\begin{array}{r}-0.0933 \\
(-1.4044)\end{array}$ & \\
\hline $\begin{array}{l}\mathrm{N} \\
\text { Number of } \\
\text { countries } \\
\text { Hausman test } \\
\text { p-value }\end{array}$ & $\begin{array}{r}214 \\
27\end{array}$ & $\begin{array}{r}241 \\
27\end{array}$ & $\begin{array}{r}241 \\
27 \\
0.0497\end{array}$ & 241 & $\begin{array}{r}214 \\
27\end{array}$ & 241 & $\begin{array}{r}241 \\
27 \\
0.4382\end{array}$ & 241 \\
\hline
\end{tabular}

Note: ${ }^{(1)}$ OLS refers to Ordinary Least Squares, ${ }^{(2)}$ FE to Fixed Effects, ${ }^{(3)} \mathrm{RE}$ to Random Effects (using generalised least squares (GLS)) and ${ }^{(4)}$ G2SLS to two-stage least-squares random-effects estimators. We used first-differencing to eliminate $\mu_{i}$, the countryspecific effects, in OLS estimation, deviations from individual means in FE and quasidemeaned variables in the case of RE. For G2SLS we used three instrumental variables - landlocked country dummy, latitude and the natural logarithm of land area. All variables are logged. All estimations (except for G2SLS) include time dummies. The statistics given in the parentheses under the coefficients of explanatory variables are t-ratio, using robust standard errors, ${ }^{7}$ except for G2SLS, where z-ratio is presented. ***,*** indicate statistically significant at $10 \%, 5 \%$ and $1 \%$ levels, respectively.

Source: Authors' calculations

\footnotetext{
7 Since panel data has time and cross-sectional dimensions, we would like that the robust estimator of the covariance matrix would correct heteroscedasticity (if variance of the error term differs across crosssectional units) and autocorrelation (if covariance of the errors across the units is non-zero in each time period). Due to this, we used the robust estimator (HAC approach) that is suggested by Arellano (2003).
} 
In the case of violent crime rates, the OLS estimate shows no evidence of statistically significant relationship with economic conditions or control variables (see Table 4). It is worth to mention here that the usage of OLS in the panel context is widely criticized mainly because this method fails to seriously address the endogeneity problem that might arise due to reverse causality or other sources. FE estimate in case of violent crime shows the evidence of a positive correlation with the population. An increase in population and having the same land area lead to higher population density and thus to more intense interactions between residents due to closer proximity. This, in turn, as FE estimate suggests, might lead to higher violent crime rates. Nevertheless, this estimate still shows no evidence of the statistically significant relationship between our core independent variables and crime rates. RE estimate shows more evidence of statistically significant relationships, but according to Hausman test results, in case of violent crime, the generalized least squares estimate cannot be considered as consistent and FE is more reliable. To address the problem of endogeneity that was detected by the Hausman test we alternatively estimated Eq. (1), using two-stage least-squares random-effects with instrumental variables that at some point have a correlation with unemployment and per capita $\mathrm{GDP}^{8}$ but are not subject to reverse causality. This estimate shows no evidence of correlation with crime rates as well.

In case of intentional homicides, according to all estimates (except for RE, that is consistent according to Hausman test, showing evidence of minor negative correlation with per capita GDP), we have to conclude that we have found no evidence of statistically significant relationships with economic conditions or control variables. In the case of property crime and unlawful acts (see Table 5), robust and consistent estimates do not provide evidence of statistically significant relationships.

\footnotetext{
8 Vast literature shows (a meta-analysis is provided by Doucouliagos and Ulubaşoğlu, 2008) that the proximity to the equator (latitude), access to the sea (landlocked countries) and the arising possibilities for the trade and expansion, openness to new ideas along with country size historically determined the establishment and type of country's legal system, economic development level, etc.
} 
Table 5: Results of robustness to estimation method (2)

\begin{tabular}{|c|c|c|c|c|c|c|c|c|}
\hline \multirow[t]{2}{*}{ Regressors } & \multicolumn{4}{|c|}{ Property Crime } & \multicolumn{4}{|c|}{$\begin{array}{c}\text { Unlawful acts involving controlled drugs or } \\
\text { precursors }\end{array}$} \\
\hline & $\mathrm{OLS}^{(1)}$ & $\mathrm{FE}^{(2)}$ & $\mathrm{RE}^{(3)}$ & G2SLS $^{(4)}$ & OLS & FE & RE & G2SLS \\
\hline Constant & $\begin{array}{r}-0.0477^{*} \\
(-1.7741) \\
\end{array}$ & $\begin{array}{l}-10.3525 \\
(-0.6955) \\
\end{array}$ & $\begin{array}{r}0.5986 \\
(0.3906) \\
\end{array}$ & $\begin{array}{l}-20.3453 \\
(-0.4893) \\
\end{array}$ & $\begin{array}{r}-0.0554 \\
(-0.5168) \\
\end{array}$ & $\begin{array}{r}-1.8739 \\
(-0.0819) \\
\end{array}$ & $\begin{array}{r}2.4634 \\
(0.8261) \\
\end{array}$ & $\begin{array}{l}-43.4653 \\
(-0.4507) \\
\end{array}$ \\
\hline $\begin{array}{l}\text { Unemployment } \\
\text { rate }\end{array}$ & $\begin{array}{r}0.2160 * * * \\
(3.0599) \\
\end{array}$ & $\begin{array}{r}0.1673 \\
(1.2321) \\
\end{array}$ & $\begin{array}{r}0.160 * * * \\
(2.7033) \\
\end{array}$ & $\begin{array}{r}1.1965 \\
(0.3469) \\
\end{array}$ & $\begin{array}{r}0.2380 \\
(0.8050) \\
\end{array}$ & $\begin{array}{r}0.0157 \\
(0.1137) \\
\end{array}$ & $\begin{array}{r}0.0386 \\
(0.3903) \\
\end{array}$ & $\begin{array}{r}2.8960 \\
(0.3609) \\
\end{array}$ \\
\hline $\begin{array}{l}\text { Real GDP per } \\
\text { capita }\end{array}$ & $\begin{array}{r}0.5206 * * * \\
(2.6594) \\
\end{array}$ & $\begin{array}{r}0.5175 \\
(1.1375) \\
\end{array}$ & $\begin{array}{r}0.4193 * * \\
(2.0714) \\
\end{array}$ & $\begin{array}{r}2.5466 \\
(0.7311) \\
\end{array}$ & $\begin{array}{r}0.6933 \\
(0.7703) \\
\end{array}$ & $\begin{array}{r}-0.0333 \\
(-0.0901) \\
\end{array}$ & $\begin{array}{r}0.4599 \\
(1.3399) \\
\end{array}$ & $\begin{array}{r}4.1611 \\
(0.5151) \\
\end{array}$ \\
\hline $\begin{array}{l}\text { Per capita } \\
\text { government } \\
\text { expenditures on } \\
\text { education }\end{array}$ & $\begin{array}{r}0.0212 \\
(0.2113)\end{array}$ & $\begin{array}{r}-0.2160 \\
(-0.7599)\end{array}$ & $\begin{array}{r}0.1328 \\
(0.7146)\end{array}$ & & $\begin{array}{r}-0.0278 \\
(-0.1229)\end{array}$ & $\begin{array}{r}-0.0214 \\
(-0.0867)\end{array}$ & $\begin{array}{r}-0.1276 \\
(-0.4154)\end{array}$ & \\
\hline $\begin{array}{l}\text { Per capita } \\
\text { government } \\
\text { expenditures on } \\
\text { police, courts } \\
\text { and prisons }\end{array}$ & $\begin{array}{r}0.0731 \\
(0.6172)\end{array}$ & $\begin{array}{r}0.4626 \\
(1.4651)\end{array}$ & $\begin{array}{r}0.2257 \\
(1.3445)\end{array}$ & & $\begin{array}{r}0.3913 * * \\
(2.1842)\end{array}$ & $\begin{array}{r}-0.0120 \\
(-0.0550)\end{array}$ & $\begin{array}{r}0.3387 \\
(1.2262)\end{array}$ & \\
\hline Population & $\begin{array}{r}-0.0923 \\
(-0.1079)\end{array}$ & $\begin{array}{r}0.7198 \\
(0.7551)\end{array}$ & $\begin{array}{r}0.0202 \\
(0.3436)\end{array}$ & & $\begin{array}{l}-3.7721 * \\
(-1.7427)\end{array}$ & $\begin{array}{r}0.1785 \\
(0.1213)\end{array}$ & $\begin{array}{l}-0.259 * * \\
(-2.2035)\end{array}$ & \\
\hline $\begin{array}{l}\mathrm{N} \\
\text { Number of } \\
\text { countries } \\
\text { Hausman test } \\
\text { p-value }\end{array}$ & 214 & 241 & $\begin{array}{r}27 \\
0.0397\end{array}$ & 241 & 214 & 241 & $\begin{array}{r}27 \\
0.6513\end{array}$ & 241 \\
\hline
\end{tabular}

Note: see the notes under Table 4

Source: Authors' calculations

Another attempt to secure the rigorousness of general estimation results was related to changing the set of control variables. According to sociological surveys, the phenomenon of crime is also determined by a number of other factors, such as quality of work, level of development of agriculture versus industry, and the traditional role of the family Instead of previously used government expenditures on education, police, courts and prison, etc., the new system-GMM estimates (see Table 6) introduce: (i) the demographic structure that is expressed by share of relatively young (15-44 years old) inhabitants in total population; (ii) a number of relatively young (15-44 years old) male immigrants; (iii) young male asylum seekers (14-34 years old males who are asylum applicants); (iv) prisoners per one hundred thousand inhabitants; (v) young (15-29 years old) males at risk of poverty or social exclusion per one thousand inhabitants; (vi) recorded per capita (15+) alcohol consumption (in litres of pure alcohol) and (vii) the shares of agriculture and industry in GDP. Allan and Steffensmeier (1989) note that and that crime is a predominant phenomenon in the developed countries and register minimum levels in the countries based on agriculture and with traditional family models. After switching to a new set of control variables, our estimates (see Table 6) regarding core independent variables remain unchanged, thus once again securing rigorousness of the general estimates. 
Mindaugas Butkus et al. • Do Economic Conditions Still Cause Crime?...

Table 6: Results of robustness check to switching control variables

\begin{tabular}{|c|c|c|c|c|}
\hline Regressors & Violent Crime & $\begin{array}{l}\text { Homicides } \\
\text { (intentional) }\end{array}$ & Property Crime & $\begin{array}{l}\text { Unlawful acts } \\
\text { involving } \\
\text { controlled drugs } \\
\text { or precursors }\end{array}$ \\
\hline $\mathrm{Y}(-1)$ & $\begin{array}{r}0.7845 * * * \\
(5.7325) \\
\end{array}$ & $\begin{array}{r}0.1548 \\
(0.7400) \\
\end{array}$ & $\begin{array}{r}0.8540 * * * \\
(3.3461) \\
\end{array}$ & $\begin{array}{r}0.6031 * * * \\
(4.8833) \\
\end{array}$ \\
\hline Constant & $\begin{array}{r}-1.4013 \\
(-1.2914) \\
\end{array}$ & $\begin{array}{r}3.5205 \\
(1.5023) \\
\end{array}$ & $\begin{array}{r}0.5024 \\
(0.9968) \\
\end{array}$ & $\begin{array}{r}1.7250 \\
(1.9832) \\
\end{array}$ \\
\hline Unemployment rate & $\begin{array}{r}0.1299 \\
(1.9986) \\
\end{array}$ & $\begin{array}{c}0.3984 * \\
(1.8935) \\
\end{array}$ & $\begin{array}{r}-0.0498 \\
(-0.6913) \\
\end{array}$ & $\begin{array}{r}0.0974 \\
(0.5982) \\
\end{array}$ \\
\hline GDP per capita & $\begin{array}{r}0.2984 \\
(0.4080) \\
\end{array}$ & $\begin{array}{r}-0.5981 \\
(-0.7430) \\
\end{array}$ & $\begin{array}{r}0.1834 \\
(0.7304) \\
\end{array}$ & $\begin{array}{r}-0.4010 \\
(-0.8032) \\
\end{array}$ \\
\hline Demographic structure & $\begin{array}{r}0.0598 \\
(0.3676) \\
\end{array}$ & $\begin{array}{r}0.9735 \\
(1.6082) \\
\end{array}$ & $\begin{array}{r}0.0591 \\
(0.2792) \\
\end{array}$ & $\begin{array}{r}0.1414 \\
(1.3287) \\
\end{array}$ \\
\hline Relatively young male immigrants & $\begin{array}{r}-0.0298 \\
(-0.3463) \\
\end{array}$ & $\begin{array}{r}0.3298 \\
(0.5926) \\
\end{array}$ & $\begin{array}{r}-0.4463 \\
(-0.3463) \\
\end{array}$ & $\begin{array}{r}-0.3953 \\
(-0.3295) \\
\end{array}$ \\
\hline Young male asylum seekers & $\begin{array}{r}0.0134 \\
(0.3443) \\
\end{array}$ & $\begin{array}{r}0.0287 \\
(0.3532) \\
\end{array}$ & $\begin{array}{r}0.0034 \\
(0.4333) \\
\end{array}$ & $\begin{array}{r}0.0523 \\
(0.3243) \\
\end{array}$ \\
\hline Prisoners & $\begin{array}{r}0.1783 \\
(0.4799) \\
\end{array}$ & $\begin{array}{r}0.8125 \\
(1.4713) \\
\end{array}$ & $\begin{array}{r}0.0587 \\
(0.3443) \\
\end{array}$ & $\begin{array}{r}0.2434 \\
(0.4913) \\
\end{array}$ \\
\hline $\begin{array}{l}\text { Young males at risk of poverty or } \\
\text { social exclusion }\end{array}$ & $\begin{array}{r}-0.0066 \\
(-0.0975) \\
\end{array}$ & $\begin{array}{r}-0.2096 \\
(-1.0235) \\
\end{array}$ & $\begin{array}{r}0.4354 \\
(0.8723) \\
\end{array}$ & $\begin{array}{r}0.2359 \\
(0.7532) \\
\end{array}$ \\
\hline Alcohol consumption & $\begin{array}{r}-0.0235 \\
(-0.9235) \\
\end{array}$ & $\begin{array}{r}0.8923 \\
(1.2957) \\
\end{array}$ & $\begin{array}{r}-0.2953 \\
(-0.9325) \\
\end{array}$ & $\begin{array}{r}0.2935 \\
(0.3296) \\
\end{array}$ \\
\hline Share of agriculture & $\begin{array}{r}-0.4934 \\
(-0.2536) \\
\end{array}$ & $\begin{array}{r}-0.5981 \\
(-0.5262) \\
\end{array}$ & $\begin{array}{r}-0.5134 \\
(-0.6252) \\
\end{array}$ & $\begin{array}{r}-0.4010 \\
(-0.2569) \\
\end{array}$ \\
\hline Share of industry & $\begin{array}{r}0.6745 \\
(0.2355) \\
\end{array}$ & $\begin{array}{r}0.5535 \\
(1.3410) \\
\end{array}$ & $\begin{array}{r}0.4873 \\
(0.2527) \\
\end{array}$ & $\begin{array}{r}0.3862 \\
(1.5325) \\
\end{array}$ \\
\hline $\begin{array}{l}\mathrm{N}^{9} \\
\text { Number of countries }\end{array}$ & $\begin{array}{r}123 \\
21\end{array}$ & $\begin{array}{r}123 \\
21\end{array}$ & $\begin{array}{r}123 \\
21\end{array}$ & $\begin{array}{r}123 \\
21\end{array}$ \\
\hline $\operatorname{AR}(2)$ test & $\begin{array}{r}1.7365 \\
{[0.1135]} \\
\end{array}$ & $\begin{array}{r}0.4760 \\
{[0.3638]} \\
\end{array}$ & $\begin{array}{r}1.0560 \\
{[0.3038]} \\
\end{array}$ & $\begin{array}{r}0.3906 \\
{[0.5814]} \\
\end{array}$ \\
\hline Sargan test & $\begin{array}{r}17.3103 \\
{[0.8994]}\end{array}$ & $\begin{array}{r}18.0314 \\
{[0.8746]}\end{array}$ & $\begin{array}{r}19.6196 \\
{[0.8092]}\end{array}$ & $\begin{array}{r}13.5952 \\
{[0.9780]}\end{array}$ \\
\hline
\end{tabular}

Note: see notes below Table 3

Source: Authors' calculations

Next robustness check is associated with changing total unemployment rate to young male (under 25 years old) unemployment rate, additionally adding GINI coefficient of equalized disposable income after social transfers to a set of core independent variables to proxy another aspect of economic conditions - income inequality that might also be associated with crime rates and, lastly, changing population to population density in a set of control variables. System-GMM estimates are provided in Table 7.

$\overline{9}$ Sample size and the number of countries of the estimations are smaller due to rather scarce data on immigration by sex and age provided in Austria, Greece, Ireland, Romania, Slovakia, and Slovenia. 
Table 7: Results of robustness check to adding/switching core independent and control variables

\begin{tabular}{|l|r|r|r|r|}
\hline \multicolumn{1}{|c|}{ Regressors } & Violent Crime & $\begin{array}{r}\text { Homicides } \\
\text { (intentional) }\end{array}$ & Property Crime & $\begin{array}{c}\text { Unlawful acts } \\
\text { involving } \\
\text { controlled drugs } \\
\text { or precursors }\end{array}$ \\
\hline Y(-1) & $0.8143^{* * *}$ & 0.1730 & $0.7751^{* * *}$ & $0.9111^{* * * *}$ \\
& $(4.1483)$ & $(1.2443)$ & $(3.3720)$ & $(2.6981)$ \\
\hline Constant & -2.5749 & -0.9023 & 1.7982 & 1.8859 \\
& $(-1.3321)$ & $(-0.3124)$ & $(0.8788)$ & $(0.3833)$ \\
\hline Yong male unemployment rate & 0.0290 & 0.0777 & -0.0407 & -0.0208 \\
& $(0.5058)$ & $(0.7130)$ & $(0.5666)$ & $(0.3833)$ \\
\hline Real GDP per capita & 0.1320 & -0.1028 & 0.0450 & -0.1406 \\
& $(0.4005)$ & $(-0.1907)$ & $(0.2965)$ & $(-0.1888)$ \\
\hline GINI (proxy for income inequality) & 0.4140 & $1.1002^{* * *}$ & -0.2793 & -0.2736 \\
& $(1.1499)$ & $(2.1669)$ & $(-0.7314)$ & $(-0.5393)$ \\
\hline Per capita government expenditures & 0.0388 & $0.6069^{*}$ & 0.0850 & 0.0772 \\
on education & $(0.1652)$ & $(1.7181)$ & $(0.4427)$ & $(0.1437)$ \\
\hline Per capita government expenditures & 0.0630 & $-0.9724 * * *$ & -0.0238 & 0.0778 \\
on police, courts and prisons & $(0.2716)$ & $(-3.2201)$ & $(-0.2147)$ & $(0.2011)$ \\
\hline Population density & 0.0015 & -0.0931 & 0.0187 & -0.0277 \\
& $(0.0379)$ & $(-1.1945)$ & $(1.0131)$ & $(-0.4558)$ \\
\hline N & 215 & 215 & 215 & 215 \\
Number of countries & 27 & 27 & 27 & 27 \\
\hline AR(2) test & 1.1848 & -0.5471 & 1.0650 & 0.5048 \\
& {$[0.2361]$} & {$[0.5843]$} & {$[0.2869]$} & {$[0.6137]$} \\
\hline Sargan test & 18.0542 & 11.5959 & 17.6764 & 12.3118 \\
& {$[0.8738]$} & {$[0.9932]$} & {$[0.8872]$} & {$[0.9893]$} \\
\hline
\end{tabular}

Note: see notes below Table 3

Source: Authors' calculations

After the above-mentioned changes in baseline Eq. (1), the estimates in terms of relationships between GDP per capita, unemployment rate, and crime rates remain like these we saw in general estimates - no evidence of a statistically significant link between economic conditions and crime rates are detected in the EU panel ${ }^{10}$. Nevertheless, we found some evidence of the positive impact of GINI on intentional homicides and negative in the case of government expenditures on police, courts, and prisons. That might suggest that higher income inequality is linked with the increase in probability to commit a crime - at least intentional homicide (we did not find evidence of statistically significant links with other forms of crime).

The last attempt of robustness check is associated with changing the model's specification to consider the possible effect of economic shock of 2008 (or any

\footnotetext{
${ }^{10}$ To account for the possibility that GDP per capita growth along with inequality could leave median, i.e. 'typical' wages unchanged, we also additionally estimated the model by incorporating interaction between GINI and GDP per capita. System-GMM estimates did not provide any statistical evidence that movements in both variables are associated with crime changes. The results are available upon request from the authors.
} 
other including changes in legislation) as plausibly exogenous to many EU countries. This is done by introducing country-specific time trends. We replaced the 'year' independent variable $\eta$ in Eq. (1) with an interaction variable of 'year $\mathrm{x}$ country'. System-GMM estimates are presented in Table 8 . The estimates of the model with country-specific time trends did not reveal any new evidence of the relationship between economic conditions and crime rates in the EU panel, except for intentional homicides. General estimates (see Table 3) and estimates with an alternative set of controls (see Table 6) showed just minor statistical evidence of a positive correlation between unemployment and intentional homicides. The estimates of the model with new specifications revealed much stronger statistical evidence to support this relationship. The estimated coefficient of elasticity is about 0.3 , indicating that an increase in unemployment by one percent is associated with a 0.3 percent higher rate of intentional homicide.

Table 8: Results of robustness check to changing the model specification

\begin{tabular}{|c|c|c|c|c|}
\hline Regressors & Violent Crime & $\begin{array}{l}\text { Homicides } \\
\text { (intentional) }\end{array}$ & Property Crime & $\begin{array}{c}\text { Unlawful acts } \\
\text { involving } \\
\text { controlled drugs } \\
\text { or precursors }\end{array}$ \\
\hline $\mathrm{Y}(-1)$ & $\begin{array}{r}0.4999 * * * \\
(2.8900)\end{array}$ & $\begin{array}{r}0.3304 * * * \\
(3.2970)\end{array}$ & $\begin{array}{r}0.5546 * * * \\
(3.4770)\end{array}$ & $\begin{array}{r}0.4991 * * * \\
(3.8820)\end{array}$ \\
\hline Constant & $\begin{array}{r}-2.1469 \\
(-1.2350) \\
\end{array}$ & $\begin{array}{r}2.2921 * \\
(1.678)\end{array}$ & $\begin{array}{r}0.8321 \\
(0.6951) \\
\end{array}$ & $\begin{array}{r}2.6708 \\
(1.2190)\end{array}$ \\
\hline Unemployment rate & $\begin{array}{r}0.1065 \\
(0.7452) \\
\end{array}$ & $\begin{array}{r}0.2848^{* * * *} \\
(3.0030) \\
\end{array}$ & $\begin{array}{r}0.0650 \\
(0.4701) \\
\end{array}$ & $\begin{array}{r}0.0243 \\
(0.2308) \\
\end{array}$ \\
\hline Real GDP per capita & $\begin{array}{r}0.1817 \\
(0.6437) \\
\end{array}$ & $\begin{array}{r}0.0175 \\
(0.0512) \\
\end{array}$ & $\begin{array}{r}0.2123 \\
(0.9153) \\
\end{array}$ & $\begin{array}{r}-0.4196 \\
(-0.8633)\end{array}$ \\
\hline $\begin{array}{l}\text { Per capita government expenditures } \\
\text { on education }\end{array}$ & $\begin{array}{r}0.1467 \\
(0.5333) \\
\end{array}$ & $\begin{array}{r}-0.0198 \\
(-0.0693) \\
\end{array}$ & $\begin{array}{l}0.2501 * \\
(1.9020)\end{array}$ & $\begin{array}{r}0.3722 \\
(1.1010) \\
\end{array}$ \\
\hline $\begin{array}{l}\text { Per capita government expenditures } \\
\text { on police, courts and prisons }\end{array}$ & $\begin{array}{r}0.0707 \\
(0.3459) \\
\end{array}$ & $\begin{array}{r}-0.2641 \\
(-1.2880) \\
\end{array}$ & $\begin{array}{r}-0.2331 \\
(-1.4550) \\
\end{array}$ & $\begin{array}{r}0.2643 \\
(0.8561)\end{array}$ \\
\hline Population & $\begin{array}{r}0.0635 \\
(1.4570)\end{array}$ & $\begin{array}{l}-0.0737 \\
(-1.483)\end{array}$ & $\begin{array}{r}-0.0054 \\
(-0.1490)\end{array}$ & $\begin{array}{r}-0.0409 \\
(-0.4564)\end{array}$ \\
\hline Country-specific time trend & $\begin{array}{r}\text { Included } 27 \\
\text { variables }\end{array}$ & $\begin{array}{r}\text { Included } 27 \\
\text { variables }\end{array}$ & $\begin{array}{r}\text { Included } 27 \\
\text { variables }\end{array}$ & $\begin{array}{r}\text { Included } 27 \\
\text { variables }\end{array}$ \\
\hline $\mathrm{N}$ & 214 & 214 & 214 & 214 \\
\hline Number of countries & 27 & 27 & 27 & 27 \\
\hline $\mathrm{AR}(2)$ test & $\begin{array}{r}1.1889 \\
{[0.2345]} \\
\end{array}$ & $\begin{array}{r}0.0669 \\
{[0.9467]} \\
\end{array}$ & $\begin{array}{r}1.2525 \\
{[0.2104]} \\
\end{array}$ & $\begin{array}{r}1.4707 \\
{[0.1414]} \\
\end{array}$ \\
\hline Sargan test & $\begin{array}{r}29.0844 \\
{[0.2940]}\end{array}$ & $\begin{array}{r}27.641 \\
{[0.4118]}\end{array}$ & $\begin{array}{r}27.0543 \\
{[0.4015]}\end{array}$ & $\begin{array}{r}29.1184 \\
{[0.3057]}\end{array}$ \\
\hline
\end{tabular}

Note: see notes below Table 3. The estimates do not include separate year dummies.

Source: Authors' calculations

To conclude, we did not find statistically strong evidence to support the link between economic conditions and crime rates, except for a positive correlation between unemployment and intentional homicides in the case of one model specification. 
Having found no empirical evidence that might link economic conditions with crime rates in the EU countries, using Eq. (1), we also made an attempt to search for the lagged crime effects of economic conditions or heterogeneous effects that could be conditional on other factors. Table 9 provides system-GMM estimates of slightly augmented Eq. (1) in terms of incorporating lagged independent variables to test an assumption that economic conditions, as well as control variables, might affect crime rates with a time lag, i.e. it takes time to adjust to new economic conditions.

Table 9: Estimates of the relationship with a time lag

\begin{tabular}{|c|c|c|c|c|}
\hline Regressors & Violent Crime & $\begin{array}{l}\text { Homicides } \\
\text { (intentional) }\end{array}$ & Property Crime & $\begin{array}{l}\text { Unlawful acts } \\
\text { involving } \\
\text { controlled drugs } \\
\text { or precursors }\end{array}$ \\
\hline$Y(-1)$ & $\begin{array}{r}0.8033 * * * \\
(6.6311) \\
\end{array}$ & $\begin{array}{r}0.1171 \\
(0.4234) \\
\end{array}$ & $0.8717 * * *$ & $\begin{array}{r}0.6553 * * * \\
(3.1714) \\
\end{array}$ \\
\hline Constant & $\begin{array}{r}-0.5410 \\
(-0.4877) \\
\end{array}$ & $\begin{array}{r}7.3226^{*} \\
(1.7517) \\
\end{array}$ & $\begin{array}{r}-0.1431 \\
(-0.1264) \\
\end{array}$ & $\begin{array}{r}2.8243 \\
(0.9058) \\
\end{array}$ \\
\hline Unemployment rate & $\begin{array}{r}0.0293 \\
(0.1148)\end{array}$ & $\begin{array}{r}-0.1148 \\
(-0.1278) \\
\end{array}$ & $\begin{array}{r}0.2719^{* * *} \\
(2.8060) \\
\end{array}$ & $\begin{array}{r}-0.0982 \\
(-0.2964)\end{array}$ \\
\hline$(-1)$ & $\begin{array}{r}0.0418 \\
(0.1429) \\
\end{array}$ & $\begin{array}{r}0.2294 \\
(0.2033) \\
\end{array}$ & $\begin{array}{r}-0.3773 * * * \\
(-3.5907) \\
\end{array}$ & $\begin{array}{r}0.1518 \\
(0.3504) \\
\end{array}$ \\
\hline Real GDP per capita & $\begin{array}{r}0.7375 \\
(0.5786) \\
\end{array}$ & $\begin{array}{r}-1.6677 \\
(-0.3143) \\
\end{array}$ & $\begin{array}{l}0.5304^{*} \\
(1.9507)\end{array}$ & $\begin{array}{r}-0.6054 \\
(-0.3829) \\
\end{array}$ \\
\hline$(-1)$ & $\begin{array}{r}-0.8207 \\
(-0.6331)\end{array}$ & $\begin{array}{r}0.6109 \\
(0.1097)\end{array}$ & $\begin{array}{r}-0.4166 \\
(-1.0890)\end{array}$ & $\begin{array}{r}0.2888 \\
(0.1555)\end{array}$ \\
\hline $\begin{array}{l}\text { Per capita government expenditures } \\
\text { on education }\end{array}$ & $\begin{array}{r}0.1551 \\
(0.5855) \\
\end{array}$ & $\begin{array}{r}0.4974 \\
(0.9907) \\
\end{array}$ & $\begin{array}{r}-0.0603 \\
(-0.4967) \\
\end{array}$ & $\begin{array}{r}0.1601 \\
(0.3553) \\
\end{array}$ \\
\hline$(-1)$ & $\begin{array}{r}-0.0269 \\
(-0.1060) \\
\end{array}$ & $\begin{array}{r}0.4508 \\
(1.3577) \\
\end{array}$ & $\begin{array}{r}0.0374 \\
(0.2391) \\
\end{array}$ & $\begin{array}{r}0.2007 \\
(0.4294) \\
\end{array}$ \\
\hline $\begin{array}{l}\text { Per capita government expenditures } \\
\text { on police, courts and prisons }\end{array}$ & $\begin{array}{r}-0.0130 \\
(-0.0570) \\
\end{array}$ & $\begin{array}{r}-0.3580 \\
(-0.6067) \\
\end{array}$ & $\begin{array}{r}0.1298 \\
(0.7541) \\
\end{array}$ & $\begin{array}{r}0.0472 \\
(0.1266) \\
\end{array}$ \\
\hline$(-1)$ & $\begin{array}{r}0.2201 \\
(0.7252) \\
\end{array}$ & $\begin{array}{r}0.0288 \\
(0.0931) \\
\end{array}$ & $\begin{array}{r}-0.0983 \\
(-0.7683) \\
\end{array}$ & $\begin{array}{r}-0.0374 \\
(-0.0863) \\
\end{array}$ \\
\hline Population & $\begin{array}{r}-0.0700 \\
(-0.0072) \\
\end{array}$ & $\begin{array}{l}-14.6017 \\
(-0.6144)\end{array}$ & $\begin{array}{r}-6.3660 \\
(-1.1439) \\
\end{array}$ & $\begin{array}{r}5.6939 \\
(0.2353) \\
\end{array}$ \\
\hline$(-1)$ & $\begin{array}{r}0.0769 \\
(0.0079)\end{array}$ & $\begin{array}{l}14.5126 \\
(0.6118)\end{array}$ & $\begin{array}{r}6.3746 \\
(1.1457)\end{array}$ & $\begin{array}{r}-5.7531 \\
(-0.2380)\end{array}$ \\
\hline $\mathrm{N}$ & 214 & 214 & 214 & 214 \\
\hline Number of countries & 27 & 27 & 27 & 27 \\
\hline $\mathrm{AR}(2)$ test & $\begin{array}{r}1.0896 \\
{[0.2759]} \\
\end{array}$ & $\begin{array}{r}-0.7149 \\
{[0.4746]} \\
\end{array}$ & $\begin{array}{r}1.1657 \\
{[0.2438]} \\
\end{array}$ & $\begin{array}{r}-0.0563 \\
{[0.9551]} \\
\end{array}$ \\
\hline Sargan test & $\begin{array}{r}11.9343 \\
{[0.9915]}\end{array}$ & $\begin{array}{r}6.9823 \\
{[0.9999]}\end{array}$ & $\begin{array}{c}10.2484 \\
{[0.9975]}\end{array}$ & $\begin{array}{r}11.7162 \\
{[0.9927]}\end{array}$ \\
\hline
\end{tabular}

Note: see notes below Table 3

Source: Authors' calculations

The estimates show no evidence of lagged crime effects of economic conditions. In case of property crimes, coefficients on unemployment rate are statistically significant but with opposite signs, thus after testing null hypothesis, using linear 
restrictions that $\{b[$ Unemployment rate $(0)]+b[$ Unemployment rate $(-1)]\}=0$, we end up with nothing but $p$-value of $\chi^{2}$ test equal to 0.17 , concluding that we have found no evidence that unemployment is linked with property crimes.

We also test the empirical assumption that the effects of economic variables on crime rates might be conditioned by countries' development levels. Despite the fact that the EU countries are among the most developed countries in the world, their development level is not uniform. If we assume that the development level shapes the impact that economic conditions might have on crime rates, we need to account for the heterogeneity of this impact. To conduct this, we interacted the unemployment rate and per capita GDP with a dummy variable ${ }^{11}$ that indicates relatively more developed EU countries. Table 10 provides the system-GMM estimates of Eq. (1) that is additionally augmented, using interactions.

Table 10: Estimates of impact heterogeneity conditional on the development level

\begin{tabular}{|c|c|c|c|c|}
\hline Regressors & Violent Crime & $\begin{array}{l}\text { Homicides } \\
\text { (intentional) }\end{array}$ & Property Crime & $\begin{array}{l}\text { Unlawful acts } \\
\text { involving } \\
\text { controlled drugs } \\
\text { or precursors }\end{array}$ \\
\hline$Y(-1)$ & $\begin{array}{r}0.8351 * * * \\
(5.5193) \\
\end{array}$ & $\begin{array}{r}0.1490 \\
(0.7865) \\
\end{array}$ & $\begin{array}{r}0.7074 * * * \\
(2.7510) \\
\end{array}$ & $\begin{array}{r}0.6517 * * * \\
(3.6190) \\
\end{array}$ \\
\hline Constant & $\begin{array}{r}-0.7878 \\
(-0.5775) \\
\end{array}$ & $\begin{array}{r}6.4741 * * \\
(2.1986) \\
\end{array}$ & $\begin{array}{r}2.1703 \\
(1.0200) \\
\end{array}$ & $\begin{array}{r}1.3868 \\
(0.4600) \\
\end{array}$ \\
\hline Unemployment rate & $\begin{array}{r}0.0448 \\
(0.6047) \\
\end{array}$ & $\begin{array}{r}0.2076 \\
(0.7905) \\
\end{array}$ & $\begin{array}{r}0.0435 \\
(0.6943) \\
\end{array}$ & $\begin{array}{r}0.0502 \\
(0.3507) \\
\end{array}$ \\
\hline $\begin{array}{l}\text { Unemployment rate * developed } \\
\text { country }\end{array}$ & $\begin{array}{r}0.0539 \\
(0.8151) \\
\end{array}$ & $\begin{array}{r}0.0488 \\
(0.1163) \\
\end{array}$ & $\begin{array}{r}-0.1903 \\
(-1.4826) \\
\end{array}$ & $\begin{array}{r}-0.0425 \\
(-0.2213) \\
\end{array}$ \\
\hline Real GDP per capita & $\begin{array}{r}0.1145 \\
(0.3504) \\
\end{array}$ & $\begin{array}{r}-0.8007 \\
(-1.1501) \\
\end{array}$ & $\begin{array}{r}-0.2360 \\
(-0.8046) \\
\end{array}$ & $\begin{array}{r}-0.3241 \\
(-0.5785) \\
\end{array}$ \\
\hline $\begin{array}{l}\text { Real GDP per capita } * \text { developed } \\
\text { country }\end{array}$ & $\begin{array}{r}-0.0039 \\
(-0.1437)\end{array}$ & $\begin{array}{r}0.0122 \\
(0.1178)\end{array}$ & $\begin{array}{r}0.0590 \\
(1.3412)\end{array}$ & $\begin{array}{r}0.0004 \\
(0.0098)\end{array}$ \\
\hline $\begin{array}{l}\text { Per capita government expenditures } \\
\text { on education }\end{array}$ & $\begin{array}{r}-0.0153 \\
(-0.0672) \\
\end{array}$ & $\begin{array}{r}0.9340 * \\
(1.9401) \\
\end{array}$ & $\begin{array}{r}0.2441 \\
(0.7970) \\
\end{array}$ & $\begin{array}{r}0.3849 \\
(0.9354) \\
\end{array}$ \\
\hline $\begin{array}{l}\text { Per capita government expenditures } \\
\text { on police, courts and prisons }\end{array}$ & $\begin{array}{r}0.0658 \\
(0.3045)\end{array}$ & $\begin{array}{r}-0.8580 \\
(-1.4895)\end{array}$ & $\begin{array}{r}0.0439 \\
(0.2897)\end{array}$ & $\begin{array}{r}0.1340 \\
(0.4206)\end{array}$ \\
\hline Population & $\begin{array}{r}0.0023 \\
(0.1050)\end{array}$ & $\begin{array}{r}-0.0266 \\
(-0.4259)\end{array}$ & $\begin{array}{r}0.0140 \\
(0.5330)\end{array}$ & $\begin{array}{r}-0.0170 \\
(-0.2896)\end{array}$ \\
\hline $\begin{array}{l}\mathrm{N} \\
\text { Number of countries }\end{array}$ & $\begin{array}{r}214 \\
27\end{array}$ & $\begin{array}{r}214 \\
27\end{array}$ & $\begin{array}{r}214 \\
27\end{array}$ & $\begin{array}{r}214 \\
27\end{array}$ \\
\hline $\mathrm{AR}(2)$ test & $\begin{array}{r}1.1812 \\
{[0.2375]}\end{array}$ & $\begin{array}{r}-0.5494 \\
{[0.5827]}\end{array}$ & $\begin{array}{c}1.01441 \\
{[0.3104]}\end{array}$ & $\begin{array}{r}0.3950 \\
{[0.6928]}\end{array}$ \\
\hline Sargan test & $\begin{array}{r}14.3906 \\
{[0.9675]}\end{array}$ & $\begin{array}{r}16.7450 \\
{[0.9166]}\end{array}$ & $\begin{array}{r}12.4780 \\
{[0.9881]}\end{array}$ & $\begin{array}{r}12.4981 \\
{[0.9880]}\end{array}$ \\
\hline
\end{tabular}

Note: see notes below Table 3

Source: Authors' calculations

${ }^{11}$ Using the average of GDP per capita over the analysed period, the countries that exceeded the average and thus are considered as relatively more developed are: Austria, Belgium, Denmark, Finland, France, Germany, Ireland, Italy, Luxembourg, Malta, the Netherlands, Spain, and Sweden. 
All estimations in Table 10 provide no evidence for the conditional and unconditional impact of economic factors on criminal activity. After interacting development level with our core independent variables, we went on interacting the two main variables of interest to see whether movements in both are necessary for crime changes. Table 11 provides system-GMM estimates.

Table 11: Estimates of interacting unemployment with per capita GDP

\begin{tabular}{|c|c|c|c|c|}
\hline Regressors & Violent Crime & $\begin{array}{l}\text { Homicides } \\
\text { (intentional) }\end{array}$ & Property Crime & $\begin{array}{c}\text { Unlawful acts } \\
\text { involving } \\
\text { controlled drugs } \\
\text { or precursors }\end{array}$ \\
\hline $\mathrm{Y}(-1)$ & $\begin{array}{r}0.762141 * * * \\
(4.6800) \\
\end{array}$ & $\begin{array}{r}0.1787 \\
(0.7071) \\
\end{array}$ & $\begin{array}{r}0.8195^{* * * *} \\
(3.8830) \\
\end{array}$ & $\begin{array}{r}0.6165^{* * *} \\
(3.0019) \\
\end{array}$ \\
\hline Constant & $\begin{array}{r}-2.0318 \\
(-0.4392) \\
\end{array}$ & $\begin{array}{r}0.7570 \\
(0.0772) \\
\end{array}$ & $\begin{array}{r}-0.3041 \\
(-0.0646) \\
\end{array}$ & $\begin{array}{r}10.1358 \\
(0.7876)\end{array}$ \\
\hline Unemployment rate & $\begin{array}{r}0.3955 \\
(0.2001) \\
\end{array}$ & $\begin{array}{r}1.5074 \\
(0.3852) \\
\end{array}$ & $\begin{array}{r}0.2390 \\
(0.1273) \\
\end{array}$ & $\begin{array}{r}-3.5227 \\
(-0.6745) \\
\end{array}$ \\
\hline Real GDP per capita & $\begin{array}{r}0.1510 \\
(0.2754) \\
\end{array}$ & $\begin{array}{r}-0.0932 \\
(-0.1000) \\
\end{array}$ & $\begin{array}{r}0.1773 \\
(0.3596) \\
\end{array}$ & $\begin{array}{r}-1.0860 \\
(-0.7814) \\
\end{array}$ \\
\hline $\begin{array}{l}\text { Unemployment rate } * \text { Real GDP per } \\
\text { capita }\end{array}$ & $\begin{array}{r}-0.0325 \\
(-0.1638) \\
\end{array}$ & $\begin{array}{r}-0.1254 \\
(-0.3131) \\
\end{array}$ & $\begin{array}{r}-0.0288 \\
(-0.1554) \\
\end{array}$ & $\begin{array}{r}0.3568 \\
(0.6803) \\
\end{array}$ \\
\hline $\begin{array}{l}\text { Per capita government expenditures } \\
\text { on education }\end{array}$ & $\begin{array}{r}0.0672 \\
(0.2860)\end{array}$ & $\begin{array}{r}0.6461 \\
(1.3050)\end{array}$ & $\begin{array}{r}0.0350 \\
(0.1393)\end{array}$ & $\begin{array}{r}0.3742 \\
(0.9199)\end{array}$ \\
\hline $\begin{array}{l}\text { Per capita government expenditures } \\
\text { on police, courts and prisons }\end{array}$ & $\begin{array}{r}0.1054 \\
(0.4755)\end{array}$ & $\begin{array}{r}-0.7522 \\
(-1.1050) \\
\end{array}$ & $\begin{array}{r}-0.0441 \\
(-0.2257) \\
\end{array}$ & $\begin{array}{r}0.0993 \\
(0.3555) \\
\end{array}$ \\
\hline Population & $\begin{array}{r}0.0261 \\
(0.8103) \\
\end{array}$ & $\begin{array}{r}-0.0229 \\
(-0.3653) \\
\end{array}$ & $\begin{array}{r}0.0014 \\
(0.0399) \\
\end{array}$ & $\begin{array}{r}-0.0616 \\
(-0.8689) \\
\end{array}$ \\
\hline $\mathrm{N}$ & 214 & 214 & 214 & 214 \\
\hline Number of countries & 27 & 27 & 27 & 27 \\
\hline $\mathrm{AR}(2)$ test & $\begin{array}{r}1.2505 \\
{[0.2111]} \\
\end{array}$ & $\begin{array}{r}-0.3358 \\
{[0.7371]}\end{array}$ & $\begin{array}{r}1.0538 \\
{[0.2920]}\end{array}$ & $\begin{array}{r}0.4444 \\
{[0.6567]}\end{array}$ \\
\hline Sargan test & $\begin{array}{r}17.4911 \\
{[0.8935]} \\
\end{array}$ & $\begin{array}{r}15.3612 \\
{[0.9504]} \\
\end{array}$ & $\begin{array}{r}20.663 \\
{[0.7591]} \\
\end{array}$ & $\begin{array}{r}11.5728 \\
{[0.9933]}\end{array}$ \\
\hline
\end{tabular}

Note: see notes below Table 3

Source: Authors' calculations

All estimated coefficients on the interaction between GDP per capita and unemployment term are statistically insignificant suggesting no evidence of necessary movements in both variables for crime rates to change.

\section{Results and discussion}

In general, the investigation results suggest that economic conditions (such as unemployment rate, per capita GDP, income inequality, etc.) do not affect crime rates in the EU countries. Our results are in contrast with findings by Raphael 
and Winter-Ebmer (2001), Papps and Winkelman (2002), Gould et al. (2002), Edmark (2005), Saridakis and Spengler (2012) who examined crime outcomes of unemployment. The reasons for these differences could be manifold. First of all, some of these studies have been carried out in non-EU countries (Raphael and Winter-Ebmer, 2001; Papps and Winkelman, 2002; Gould et al., 2002). Other studies (Edmark, 2005; Fougere et al., 2009; Enfort, 2009; Saridakis and Spengler, 2012) were conducted by using data on separate EU countries (Sweden, France, Germany, Greece) at a different level of aggregation. The relationship between economic conditions and crime may be stronger if analysed not at a country, but at the level of smaller geographic units. Secondly, even if the country's unemployment rate increases and people face financial problems, only a part of them choose a criminal path and this does not necessarily influence a level of crime significantly. Thirdly, the strength of the relationship between economic conditions and crime can be influenced by the estimation method and control variables used in the model. To eliminate this impact, we provided an extensive robustness check $^{12}$ as well as made an attempt to find other than a simple linear form of relationship ${ }^{13}$. However, this did not change the general results of the study.

The results similar to ours are provided by Buonanno et al. (2011), who covered seven European countries and the USA, Engelen et al. (2016), who used data of 100 North Carolina (USA) counties, and Malby et al. (2012), who used data of 15 different countries, of which only three are the EU countries. It should be noted that only Malby et al.'s (2012) research used GDP as a proxy of economic condition.

Thus, our results not only support the economic explanation of the crime but also provide important findings for the EU crime prevention policy including local politicians, law enforcement agencies and the judicial system, social services, education system, civil society organisations, industry, banks, private sector, research workers and scientists, and the general public. Our study fills the gap in this research area, using EU panel data. The study also revealed the direction for further research: orientation towards social and demographic factors and research at a lower level of disaggregation. The study also contributes to methodological issues, as the results revealed statistically significant and positive relationships between the current crime rate and one-year lagged crime rate (except in case of international homicides). This empirical finding strongly supports the arguments of Baltagi (2006), Ghasemi (2017) among others, that the relationship between

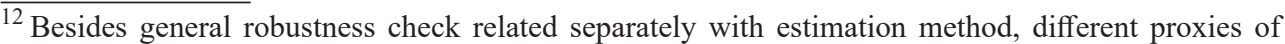
economic conditions, as well as different set of control variables that is provided in the article, full performed robustness check also include aggregation of different types of crime, blending separate aspects of robustness check, omitting the outliers, etc. The results are available upon request from the authors.

${ }^{13}$ Besides what is provided in the article, it also includes a search for an effect with longer than one-year lag, non-linear form of relationship, etc. The results are available upon request from the authors.
} 
crime and economic performance should be analysed in a dynamic framework. This means that past crime rates in the country should be treated as an important independent variable to control the potential effects of unobserved historical factors on current economic performance and crime rate. This is in line with Wooldridge's (2010) statement that adding a lagged outcome variable to proxy omitted variables is a simple and useful way to account for historical factors having effects on the dependent variable. This also means that other static estimators which ignore the dynamic nature of the relationship between crime and economic performance may be biased (Entorf and Spengler, 2000). This finding, therefore, supports the recent challenge for applying the dynamic panel GMM estimator in examining crime in particular (Greenberg, 2014), as well as in social studies in general (Pindado and Requejo, 2015).

\section{Conclusions}

The orthodox approach explaining the relationship between different economic factors and crime rates postulates that negative changes in the economy lead to higher crime rates, while positive changes decrease the rates of criminal activity. The results of this research show that there is no clear evidence of this type of relationship. Our general estimates using real GDP per capita and the unemployment rate as the main proxies for economic conditions, and systemGMM as the main estimation strategy provide no statistically significant evidence of the link between economic conditions and crime rates within the framework of the proposed model. To secure the rigorousness of these findings, we provided an extensive robustness check as well as made an attempt to find other than a simple linear form of relationship. All that did not change our general empirical finding - we found no evidence of the effects of economic conditions on crime rates in EU panel, except for intentional homicides in some model specifications. One of the reasons for our findings might be that the relationship between economic conditions and crime may be stronger if analysed not at a country, but at the level of smaller geographic units. This can be explained by cultural specificity and differences regarding regional economic conditions and societal reactions to the economic changes. The further research focusing on a smaller, i.e. regional level, might provide a more homogenous population of potential criminals who may tend to act more similarly than the whole population of potential criminals at a national level. 


\section{References}

Allan, E. A., Steffensmeier, D. J. (1989) "Youth, underemployment, and property crime: Differential effects of job availability and job quality on juvenile and young adult arrest rates", American sociological review, Vol. 54, No. 1, pp. 107-123, http://doi.org/10.2307/2095665.

Arellano, M. (2003) Panel Data Econometrics, Oxford: Oxford University Press.

Arellano, M., Bond, S. (1991) "Some tests of specification for panel data: Monte Carlo evidence and an application to employment equations", The Review of Economic Studies, Vol. 58, No. 2, pp. 277-297, http://doi.org/10.2307/2297968.

Arellano, M., Bover, O. (1995) "Another Look at the Instrumental-Variable Estimation of Error-Components Models", Journal of Econometrics, Vol. 68, pp. 29-52, http://doi.org/10.1016/0304-4076(94)01642-D.

Baltagi, B.H. (2006) "Estimating an economic model of crime using panel data from North Carolina", Journal of Applied Econometrics, Vol. 21, No. 4, pp. 543-547, http://doi.org/10.1002/jae.861.

Blundell, R., Bond, S. (1998) "Initial conditions and moment restrictions in dynamic panel data models", Journal of Econometrics, Vol. 87, No. 1, pp. 115143, http://doi.org/10.1016/s0304-4076(98)00009-8.

Brosnan, S. (2018) "The Socioeconomic Determinants of Crime in Ireland from 2003-2012", The Economic and Social Review, Vol. 49, No. 2, pp. 127-143.

Buonanno, P., Drago, F., Galbiati, R., Zanella, G. (2011) "Crime in Europe and the United States: Dissecting the "Reversal of Misfortunes", Economic Policy, Vol. 26, pp. 347-85, http://doi.org/10.1111/j.1468-0327.2011.00267.x.

Cook, P.J., Zarkin, A.G. (1985) "Crime and the Business Cycle", The Journal of Legal Studies, Vol. 14, No. 1, pp. 115-128, http://doi.org/10.1086/467767.

De Blasio, G., Maggio, G., Menon, C. (2016) "Down and out in Italian towns: measuring the impact of economic downturns on crime", Economics Letter, Vol. 146, pp. 99-102, http://doi.org/10.1016/j.econlet.2016.07.034.

Dix Carneiro, R., Soares, R.R., Ulyssea, G. (2016) Local labor market conditions and crime: Evidence from the Brazilian trade liberalization, IZA Discussion Papers No. 9638, http://doi.org/10.2139/ssrn.2895107.

Doucouliagos, H., Ulubaşoğlu, M.A. (2008) "Democracy and economic growth: a meta-analysis", American Journal of Political Science, Vol. 52, No. 1, pp. 6183, http://doi.org/10.1111/j/1540-5907.2007.00299.x.

Doyle, J.M., Ahmed, E., Horn, R.N. (1999) "The Effects of Labor Markets and Income Inequality on Crime: Evidence from Panel Data", Southern Economic Journal, Vol. 65, No. 4, pp. 707-738, http://doi.org/10.2307/1061272.

Edmark, K. (2005) "Unemployment and crime: Is there a connection?", Scandinavian Journal of Economics, Vol. 107, No. 2, pp. 353-373, http://doi. org/10.1111/j.1467-9442.2005.00412.x. 
Ehrlich, I. (1996) "Crime, Punishment and the Market for Offences", Journal of Economic Perspectives, Vol. 10, No. 1, pp. 43-67, http://doi.org/10.1257/jep.10.1.43.

Engelen, P.J., Lander, M.W., van Essen, M. (2016) "What determines crime rates? An empirical test of integrated economic and sociological theories of criminal behaviour", The Social Science Journal, Vol. 53, No. 2, pp. 247-262, http://doi. org/10.1016/j.soscij.2015.09.001.

Entorf, H. (2009) "Crime and the labour market: Evidence from a survey of inmates", Journal of Economics and Statistics, Vol. 220, No. 2-3, pp. 254-269, http://doi.org/10.1515/jbnst-2009-2-311.

Entorf, H., Spengler, H. (2000) "Socioeconomic and demographic factors of crime in Germany: Evidence from panel data of the German states", International review of law and economics, Vol. 20, No. 1, pp. 75-106, http://doi.org/10.1016/ s0144-8188(00)00022-3.

Fajnzylber, P., Lederman, D., Loayza, N. (2002) "What causes violent crime?", European Economic Review, Vol. 46, No. 7, pp. 1323-1357, http://doi. org/10.1016/s0014-2921(01)00096-4.

Fougere, D., Kramarz, F., Pouget, J. (2009) "Youth Unemployment and Crime in France", Journal of the European Economic Association, Vol. 7, No. 5, pp. 909-938, http://doi.org/10.1162/jeea.2009.7.5.909.

Ghasemi, M. (2017) "Crime and punishment: evidence from dynamic panel data model for North Carolina (2003-2012)", Empirical Economic, Vol. 52, No. 2, pp. 723-730, http://doi.org/10.1007/s00181-016-1093-5.

Gould, E.D., Weinberg, B.A., Mustard, D.B. (2002) "Crime rates and local labor market opportunities in the United States: 1979-1997" The Review of Economics and Statistics, Vol. 84, No. 1, pp. 45-61, http://doi.org/10.1162/003465302317331919.

Greenberg, D.F. (2014) “Studying New York City's crime decline: methodological issues", Justice Quarterly Vol. 31, No. 1, pp. 154-188, http://doi.org/10.1080/ 07418825.2012.752026.

Hargaden, E. (2016) "Crime and Unemployment in Ireland, 2003-2016". Available at: http://www.hargaden.com/enda/hargaden_crime.pdf [Accessed: May 3, 2018]

Hayakawa, K. (2007). "Small sample bias properties of the system GMM estimator in dynamic panel data models", Economics Letters, Vol. 95, No. 1, 32-38, http://doi.org/10.1016/j.econlet.2006.09.011.

Hazra, D., Cui, Z. (2018) "Macroeconomic Determinants of Crime: Evidence from India", Journal of Quantitative Economics, Vol. 16, No. 1, pp. 187-198, http:// doi.org/10.1007/s40953-018-0127-6.

Levitt, D.S. (1996) "The Effect of Prison Population Size on Crime Rates: Evidence from Prison Overcrowding Litigation", The Quarterly Journal of Economics, Vol. 111, No. 2, pp. 319-351, http://doi.org/10.2307/2946681. 
Malby, S. et al. (2012). Monitoring the impact of economic crisis on crime. United Nations Office on Drugs and Crime.

Melick, M.D. (2003) "The relationship between crime and unemployment", The Park Place Economist, Vol. 11, No. 1, pp. 29-36.

Mustard, D.B. (2010) How do labor markets affect crime? New evidence on an old puzzle, IZA Discussion Paper No. 4856.

Papps, K., Winkelmann, R. (2002) "Unemployment and Crime: New Evidence for an Old Question", New Zealand Economic Papers, Vol. 34, No. 1, pp. 53-72, http://doi.org/10.1080/00779950009544315.

Pare, P.P., Felson, R. (2014) "Income inequality, poverty and crime across nations", The British Journal of Sociology, Vol. 65, No. 3, pp. 434-458, http://doi. org/10.1111/1468-4446.12083.

Pindado, J., Requejo, I. (2015) Panel data: a methodology for model specification and testing, Wiley Encyclopedia of Management.

Raphael, S.L., Winter-Ebmer, R. (2001) "Identifying the Effect of the Unemployment on Crime" Journal of Law and Economics, Vol. 44, No. 1, pp. 259-283, http://doi.org/10.1086/320275.

Rose, D. (2006) Poverty and crime. In: Serr, K. (ed.): Thinking about poverty, Federation Press: Annandale, N.S.W., pp. 107-117.

Rosenfeld, R., Fornango, R. (2007) "The impact of economic conditions on robbery and property crime: the role of consumer sentiment", Criminology, Vol. 45, No. 4, pp. 735-769, http://dx.doi.org/10.1111/j.1745-9125.2007.00096.x.

Saridakis, G., Spengler, H. (2012) "Crime, deterrence and unemployment in Greece: A panel data approach", Social Science Journal, Vol. 49, pp. 167-174, http://doi.org/10.1016/j.soscij.2011.08.005.

Soto, M. (2009) System GMM Estimation with a Small Sample, UFAE and IAE Working Papers 780.09, Barcelona, Spain: Centre d'Estudis Olímpics.

Widner, B., Reyes-Loya, M.L., Enomoto, C.E. (2011) "Crimes and violence in Mexico: Evidence from panel data”, The Social Science Journal, Vol. 48, No. 4, pp. 604-611, http://doi.org/10.1016/j.soscij.2011.03.003.

Windmeijer, F. (2005) "A finite sample correction for the variance of linear efficient two-step GMM estimators", Journal of Econometrics, Vol. 126, No. 1, pp. 2551, http://doi.org/10.1016/j.jeconom.2004.02.005.

Wooldridge, F.M. (2010) Econometric Analysis of Cross Section and Panel Data, 2nd ed. MIT Press: Cambridge, Massachusetts; London, England.

Wrigley-Asante, C. (2016) "Gendered perception of crime and safety: Insights from different socio-economic urban neighbourhoods in Ghana", Ghana Journal of Geography, Vol. 8, No. 1, pp. 103-123. 


\title{
Da li gospodarski uvjeti i dalje uzrokuju zločin? Neki uvjerljivi empirijski dokazi iz EU panela
}

\author{
Mindaugas Butkus ${ }^{1}$, Kristina Matuzevičiūtè ${ }^{2}$, Alma Mačiulytè-Šniukiené $\dot{3}^{3}$
}

\begin{abstract}
Sažetak
Povećanje stope kriminala dovodi do povećanja osjećaja straha $i$ tjeskobe $u$ društvu $i$ narušavanja društvenog poretka $i$ sklada u zemlji. U posljednjim desetljećima mnogi znanstvenici opisuju pad gospodarskih čimbenika kao što su BDP po glavi stanovnika, stope nezaposlenosti, siromaštvo itd., kao primarni pokretači kriminala kako u razvijenim tako i u zemljama u razvoju. Čak i tijekom razdoblja gospodarskih kriza, stopa kriminala u Europskoj uniji (EU) nastavila je opadati ili ostaje ista, dovodeći u pitanje utjecaj ekonomskih čimbenika na stopu kriminala u EU. U radu se ispituje utjecaj promjenjivih gospodarskih uvjeta na stopu kriminala u zemljama EU-a uz primjenu danas široko korištenih ekonomskih metoda za rješavanje problema endogenosti. Cilj je rada empirijski procijeniti odnos između stope kriminala $i$ ekonomskih čimbenika, koristeći prethodno razvijene metode. Nakon niza provjera robusnosti, procjene nisu pružile dokaz značajne povezanosti između ekonomskih uvjeta $i$ stope kriminala tijekom posljednjeg desetljeća u zemljama EU-a, osim ubojstava u nekim specifikacijama modela.
\end{abstract}

Ključne riječi: stope kriminala, prevencija kriminala, ekonomski uvjeti, panel podaci, GMM procjenitelj

JEL klasifikacija: K14, K42, E32

${ }_{1}$ Izvanredni profesor, Department of Economic Engineering, Vilnius Gediminas Technical University, Sauletekio av. 11, LT-10223 Vilnius, Litva. Znanstveni interes: kvantitativne metode u ekonomiji, ekonometrija.Tel.: +37067102658.E-mail: mindaugas.butkus@vgtu.lt.

2 Izvanredni profesor, Department of Economic Engineering, Vilnius Gediminas Technical University, Sauletekio av. 11, LT-10223 Vilnius, Litva. Znanstveni interes: nacionalni $i$ regionalni razvoj, međunarodna radna migracija. Tel.: +370 614 33446. E-mail: kristina. matuzeviciute-balciuniene@vgtu.lt.

3 Izvanredni profesor, Department of Business Technologies, Vilnius Gediminas Technical University, Sauletekio av. 11, LT-10223 Vilnius, Litva. Znanstveni interes: regionalni razvoj, konkurentnost. Tel.: +370652 71009. E-mail: alma.maciulyte-sniukiene@vgtu.lt (osoba za kontakt). 